\title{
Avrupa Bütünleşmesi Sürecinde: Hukuk, Devlet Ve Egemenlik Tartışmaları
}

Murat ALAKEL *

\section{Özet}

Bu makale öncelikli olarak, 'Vestfalya Avrupa ulus devlet sisteminin, Vestfalya sonrası düzende uluslararası entegrasyonda uluslararası sistemde, nasıl Avrupa Birliği üye devleti haline geldiğgi' tartışmalarını inceler. İkinci olarak Avrupa entegrasyon süreci, tarihsel içerikle uluslararası örgütlerin gelişimi çerçevesinde ele alınmıştır. Sonrasında, Avrupa Birliği ve üye devletler içinde AB'nin siyasî yapısı hakkında devlet, hükümetler-arası, ulus-üstü örgüt gibi yaklaşımlar da tartışılmıştır. Ayrıca AB hukuku ve uluslararası hukuk çerçevesinden, AB'nin statüsü ve hukuk yapım süreci açıklanmıştır. Son olarak $A B$ ve üye devletler içinde egemenlik bağlamında yapılan çeşitli teorik ve kavramsal katkılar derlenmiştir. Bu çalışmanın temel katkısı Lizbon Anlaşması'na kadar olan Avrupa Birliği sürecinde ulus devletin dönüşümü bağlamında hukuki, devlet ve egemenlik okumalarının genel bir eleştirel okumasını yaparak teorik düzeyde kavramsal bir içerik oluşturmak olmuştur. Esas olarak bu makale, ikincil kaynakların okunması ve yorumlanması sürecinde tanımlayıcı ve tartışma yöntemleriyle, analitik bir eleştirel yaklaşımla yazılmıştır.

Anahtar Kelimeler: Ulus Devlet, Üye Devlet, Avrupa Entegrasyonu, Avrupa Düzeni, AB Hukuku, Egemenlik.

\section{European Integration Process: Law, State And Sovereignty Discussions}

\section{Abstract}

That article firstly aims to cover the discussions of that how European Westphalian nation state system tries to form a Post-Westphalian order as a member state in the European Union via International Integrations in the current Internati-

* Yrd. Doç. Dr., Yalova Üniversitesi, Uluslararası İlişkiler Bölümü, Öğretim Üyesi, muratalakel@ hotmail.com 
onal system. Secondly, it is explicated in which the historical evolutions of European Integration processes and the expansions of the International organisations. Later, it is elaborated that how EU Integration politically shaped related to state affairs in the European Union and State Structures among the member states. Thereupon, it includes also EU law and International law matters. At last, it comprises resourceful theoretical and conceptual articulations of the transformations of national sovereingty discussions within the EU and member states. The main contribution of that study is to make a theoretical and conceptual content within the critical reviews of the legal, state and sovereignty literatures which more needed to restructure nation state in the EU regional integration readings by the time of Lisbon Agreement. Moreover, that essay written having read secondary resources, onwhich it is used the descriptive and discursive methodology within the framework of analytical, and critical perspectives.

Keywords: Nation State, Member State, European Integration, European Order, European Union Law, Sovereignty.

\section{Giriş}

Avrupa Topluluğu, 20. yüzyılın sonunda küreselleşmeyle birlikte, Hugo Grotious'un teorisini oluşturduğu uluslararası hukukun üzerine oturduğu ülkesel egemenlik anlayışını değiştirerek, yeni bölgesel yaklaşımların (serbest devlet gibi) karşılıklı ekonomik bağımlılığını ve evrensel insan hakları ilkesini barışçıl bir şekilde dönüştürerek yeni bir düzen oluşturmuştur (Khan, 1992, s1-8).

Avrupa, ilk defa egemen ulus devlet düşüncesini ortaya çıkaran ve bu siyasayı dünyaya yayan bir kıta olarak pratikte bu ulus devlet yap1sını -AET adı altında altı Avrupa ülkesi arasında imzaladığı antlaşmayla malların, halkların, hizmetin ve sermayenin serbestçe dolaştığı bir alan amaçlayarak- dönüştürmektedir (Linberg,1963,s.3-4). Burada kendisine has kitasal ve küresel bir entegrasyon stratejisi belirlemiştir (Bankska Bystrica, 2001, s.7-47). Aynı şekilde AB, Avrupa entegrasyon sürecinde post-modern dönemin ihtiyaç ve sorunlarının üstesinden gelmek için, demokratik meşruiyet arayışının içerisinde olarak, yeni bir hükümet modelini oluşturmaktadır. Bu modelin oluşturulması başka bir coğrafyada çok zordur (Bankska Bystrica, 2004, s.9).

YIL: 5 SAYI: 10 
Batı Avrupa devletleri, 20. yüzyılın ortasından itibaren siyasi, hukuki, ekonomik (Amin ve Dietrich, 1991), sosyal ve toplumsal alanda kendi aralarında barış ve istikrarı sağlamak için işbirliğini amaçlamışlardır (Alakel, 2008, s100-125). Ancak günümüzde bu ülkeler, Avrupa Birliği üye devletlerinde yaşayan birey için egemen ulus devletten farklı olarak, bireyin $\mathrm{AB}$ düzeyinde temel hak ve görevlerini belirleyen makro bölgesel alanda yeni bir siyasi, hukuki ve ekonomik yaşam alanı oluşturmuşlardır (Tezcan, 2002, s11). Avrupa ayrıca küreselleşme sürecinin belirsizlikleri içinde kendi toplum modelini, yani refah devletini geliştirmeyi hedeflemiştir (Koray, 2005, s181). Bu makalede öncelikle Avrupa uluslararası entegrasyonunu tarihsel perspektiften ele alacağız. Sonrasında kısmen teorik olarak uluslararası örgütlerin gelişimi, bölgeselleşme ve bölgesel entegrasyon ve savaş sonrası süreçte $A B$ bütünleşmesinin Lizbon Anlaşmasına kadar olan süreci inceleyeceğiz. Ayrıca Ulusal ve Uluslararası hukuk açısından $\mathrm{AB}$ hukuk düzeninin temel özellikleri işlenecektir. Son olarak ise AB'de egemenlik ve devlet tartışmaları ele alınacaktır. Tarihsel çerçeveden günümüze kadar olan süreçte siyasi, hukuki ve ekonomik bağlamda ulus devlet, uluslararası örgütler, uluslararası sistemdeki yeri, devlet ve egemenlik gibi farklı çerçeveleri içine alan Avrupa bütünleşmesinin nasıl şekillendiği ve ulus devlet çerçevesinde egemenlik nosyonunun nasıl dönüştürüldüğü kapsamlı bir bağlamda tartışılacaktır. Bu yönüyle $A B$ ile birlikte ifade edilen devlet ve egemenlik gibi birçok kavram, açıklama ve tanımlamaları sistematik şekilde özetlenerek analiz edilmeye çalışılmıştır.

\section{Avrupa Entegrasyonun Tarihine Bakış}

$\mathrm{AB}$ - son şekliyle gelinen süreçte ve söz konusu süreçten çok daha eski dönemlerde- Avrupa'nın birleşmesi ve bütünleşmesi yönünde önemli çabalar göstermiş ve bu girişimlerde siyasi, ekonomik, askerî, güvenlik, savunma, dış politika konularında ve egemen ulus-devletlerin farklı çıkar çatışmalarıyla ilgili birçok konuda rol oynamıştır. Avrupa'yı birleştirme çabaları, Charlagmane ile Habsburg Hanedanlığı'nda başlayıp Napolyon ve Hitler'e kadar olan dönemdeki siyasi liderler gibi, askerî güç ve şiddet kullanılarak emperyal bir egemenlik altında başarısız fetih savaşlarıyla 
sürdürülmek istenmiştir. Ancak, idealist bir söylem olarak Avrupa'nın birleşmesi, bütünleşmesi ve bu bağlamda Avrupa'da ortak bir birlik kurmaya yönelik hareketlere birçok düşünür ve siyasetçi, eski Roma İmparatorluğunun medeni Avrupa'yı barış ve birlik içinde yönetmesinden esinlenerek vurgu yapmıştır. Örneğin, yargıç ve diplomat olarak İngiltere ve Fransa'da görev yapan Pierre Dubois, 1306'da prenslerden oluşan sürekli bir meclisin Hıristiyan prensipleri üzerine barışı sağlayacağını söylemiştir. Maximilien de Bethune ve Duc de Sally, federal devlet birliğinin Türklere karşı Avrupa'yı daha iyi savunacağını söylemiştir (Urwin, 1995, s1-2).

Ayrıca, Duc de Sally, 1638'de basılan ‘Anılar' adlı eserinde Avrupa'da barış1 ve düzeni sağlamak için bir federasyon öngörmüş ve bu federal yapıda Türkleri Hıristiyan olmadıkları için, Rusları da "yanlış bir Hıristiyanlık” (Ortodoksluk) üzere oldukları için dışlamıştır. Piskopos Roxas, 1665 'teki “Roxas Projesi”nde ve William Penn, 1693'de Avrupa'da barışın sağlanması amacı ile çeşitli birleşmeler önermişlerdir. John Beller, 1710'da yayınladığ 1 bir eserinde her y1l toplanacak bir 'Kongre'den bahsederken, Abbé de Saint Pierre de 1712'deki “Avrupa'da Barışı Sürekli Kılma İçin Proje" adlı çalışmasında Avrupa devletlerinin temsilcilerinden oluşacak bir 'Senato'dan bahsetmektedir (Dedeoğlu,1996, s.61-76) . Voltaire, Rousseau, Montesquieu, Kant gibi o dönemin birçok düşünürünün yazdığ1 eserlerden, yükselmekte olan ortak bir Avrupa yapılanmasına örnekler gösterilebilir. Adından bahsettiğimiz ve bahsetmediğimiz birçok Avrupalı yazar, ortak tarihsel ve kültürel deneyimden beslenen "Avrupalılık” duygusu ve Avrupa fikri temalarını işlemişlerdir. Voltaire, Avrupa'yı "aynı dinî temeli, aynı kamu hukuku ve siyaset ilkelerini benimseyen, birçok devlete bölünmüş bir tür cumhuriyet" olarak nitelendirmiştir (Dedeoğlu,1996, s. 62-68). Avrupa'da birlik oluşturma düşüncesi, bölgede millî devletlerin ortaya çıkışıyla da eş tarihlidir. Papalık ve Kutsal Roma İmparatorluğu bu ulus devlet oluşumunu, 'Respublica Christiana'nın yıkılması ve bölünmesine tehdit olarak görmüştür.

Kant ise 17. yüzyılda "Ebedi Barış" adlı eserinde Avrupa'da barışı sağlayacak bir birlik veya federasyon önermiştir. 18. yüzyılın ortalarından 19. yüzyıla dek Avrupa'da barışı sağlayacak otuz kadar birlik önerisi ileri sürülmüştür (Dedeoğlu,1996, s. 64). Çünkü Avrupa'da sanayileşme 
devriminin başlamasıyla artan sanayi üretimiyle pazar arayışları, ulusal ve kıtasal ölçekte birlik düşüncesine hız kazandırmıştır. Avrupa'da fazla üretim için yerel ve ulusal gümrük tarifelerinin indirilmesi gerekiyordu. 1786 Fransız - İngiliz Ticaret Antlaşması imzalanmış; ancak Fransız Devrimi anlaşmanın yürürlüğe girmesini engellemiştir. 1815 Viyana Kongresi sonrasında Prusya' da "Maassen Tarifesiyle" iç gümrükler kaldırılmıştır. 1828 yılından itibaren Prusya, Alman devletleri arasında "Zollverein" gümrük birliğini kurarak siyasal birlik sürecini hızlandırmıştır (Hasgüler ve Uludağ, 2010, s.49-50). Bismark 1871'de Alman Siyasal Birliği'ni kurarak ortak gümrük tarifesine geçer. Bu süreçte İngiliz ve Fransızlar, 1860 Ticaret Antlaşmasıyla gümrükleri indirirler. 1862 de Fransa ve Prusya gümrük tarifelerini indirir. Fakat 19. yüzyılın sonunda meşhur Alman iktisatçı Frederich List'in korumacı fikirlerinden etkilenen Almanya, Fransa ve İtalya gümrüklerini yükseltir ve 1870-1914 arası Avrupa devletleri kapalı ve korumac1 politikalar izlerler (Karluk, 1996, s37-38).

Avrupa devletleri arasında bir güç dengesi mekanizması ve "Avrupa Uyumu” Aydınlanma düşünürleri tarafından idealize edildiği şekilde; Ancak 19. yüzyılda kurulabilmiştir. 1814'te basılan “Avrupa Topluluğu'nun Reorganizasyonu” adlı eserinde, Comte de Saint-Simon, dış politika, ekonomi, iletişim, eğitim ve hatta din ve ahlakî konular gibi Avrupalıların ortak meselelerinden sorumlu olacak tek bir Avrupa hükümeti ile Avrupa Parlemontosu'ndan oluşacak bir Avrupa federal örgüt modelini, bir Avrupa Birleşik Devletleri projesini önermiştir (Bozkurt, 1997, s29-75). 18141815 'te toplanan Viyana Kongresi, esasında Fransız devrimi ve Napolyon savaşları neticesinde bozulan Avrupa düzenini yeniden restore ederek modern tarihte Vestfalya sistemi kadar önemli kabul edilerek Avrupa devletleri arasındaki uyum ve işbirliğini sürdüren, diplomatik, siyasi ve askeri bir oluşumdur (Hasgüler ve Uludağ, 2010, s.17).

19. yüzyılda Avrupa'da bütünleşme olgusuna bakışı en iyi özetleyenlerden biri olan Victor Hugo (1848), “ABD nasıl yeni bir dünyayı taçlandırdı ise, bir gün gelecek Avrupa Birleşik Devletleri de eski dünyayı süsleyecektir.” (Karluk, 1996, s. 37-39) demiştir. Ayrıca Hugo “... Siz Fransızlar, siz İtalyanlar, siz İngilizler, siz tüm kıtanın ulusları, onurunuzdan, niteliklerinizden hiçbir şey kaybetmeden bir gün gelecek yük- 
sek düzeyde bir birlik oluşturacak ve Avrupa' da kardeşliği kuracaksınız." (Dedeoğlu,1996, s. 66) ifadesiyle Avrupa'da birleşme fikrini ortaya atmıştır. 20. yüzyılın ilk yarısında bütünleşme, önemli devlet adamlarının isimleri ile anılan ve örgütsel girişimlere dönüşen bir nitelik kazanmıştır. Jean Monnet, Robert Schuman, Konrad Adenauer, Carlos Sfersa, Winston Churchill ve Henri Spaak gibi isimleri örnek olarak sayabiliriz (Bozkurt, 1997, s.43-72). Count Richard Coudenhove-Kalergi ve Aristide Briand'ın düşünce ve çabalarıyla, "Pan-Avrupa Birliğì", "Federal Avrupa Birliğii”, ya da "Avrupa Birliği” kavramlarının kurumsal altyapısı için gerekli olan zihinsel birikimde önemli mesafeler alınmıştır. Aristide Briad, 1929 yılında Milletler Cemiyeti içinde Avrupa Federal Birliği adıyla bir birim kurulmasını istemiş, daha sonra İngiltere Başbakanı Churchill bu düşünceleri desteklemek amaciyla Avrupa'da ABD benzeri kıtasal ölçekte bir devlet örgütlenmesine gidilmesi gerektiğini savunmuştur (Ülger, 2002, s49-50).

$\mathrm{AB}$ entegrasyon sürecinin tarihsel ve teorik altyapısının anlaşılmasında yeni uluslararası düzende uluslararası örgütlerin kurulması ve entegrasyon teorilerinin kısaca özetlenmesi; çalışmada ele alınan entegrasyon sürecinde hukuk, egemenlik ve devlet tartışmalarına teorik ve kavramsal temel oluşturacaktır.

\section{Uluslararası Örgütlerin Oluşumu ve Gelişimi Hakkında Teorik Tartışmalar}

Uluslararası örgütün tanımı "siyasal olarak bağımsız egemen devletler ya da devlet-dışı aktörlerin global, bölgesel, ikili veya çoklu uluslararası alanda özel veya genel amaçlarını gerçekleştirmek için inşa edilen yapı, sistem ve kurumlardır.” (Hasgüler ve Uludağ, 2010, s.1) şeklinde yapı1ır. Uluslararası örgütlerin gelişmesi, hem Avrupa'da hem de uluslararası sistemde devletlerin işbirliğini artıran yeni bir düzen başlatmıştır. Savaş sonrası süreçte, uluslararası sisteme yeni devletlerin katılması ile birlikte küresel ve bölgesel; ekonomik, siyasî, finansal, askerî ve güvenlik yap1larının oluşturulması ihtiyacı doğmuştur. Dolayısıyla, uluslararası arenada ülkelerin kendi halkının ihtiyaçlarını, kalkınma ve gelişme taleplerini sürdürülebilir şekilde karşılamak için Bretton Wood, ITO, GATT, OECD, 
AT, IMF, Dünya Bankası ve COMECON gibi birçok ortak işbirliği örgütleri kurulmuştur. Ülkeler arasındaki işbirliğini askerî, siyasî alanlarda II. Dünya Savaşı sonunda BM, NATO, Varşova Paktı gibi yeni ortak güvenlik kurumları şekillendirmiştir.

Uluslararası kurumlar, bölgesel ve küresel ölçekte entegrasyonu teşvik eder. Devletler arasında işbirliğinin artması, ulus-üstü kurumlara tedrici olarak yetkilerin devri, ortak değerlerin oluşturulması ve küresel ölçekte halklar arasında ortak bir dayanışma oluşturan siyasi bir topluluk kurulması ile hem AB gibi bölgesel hem de BM gibi küresel bir yönetişimin entegrasyon sistemi gerçekleşmiş oldu (Giffiths\&O'Callaghan, 2004, s155-156). Bu yönüyle örgütlerin devlet egemenliğini aşındırdığı söylenir. Çünkü, örgütleri kuran devletler meşru bir rasyonel yetki sahası, teknik uzmanlık ve bilgiden dolayı bu kurumların otonom bir güç kazanmış gibi görünmelerini bazen ulusal çıkarını önceleyen hükümetlerarasıcılık yaklaşımıyla törpüler; $\mathrm{AB}$ ise bu tam egemen devletçi bakışa meydan okuyan bir yapıya sahiptir (Barnett\&Finnemore, 2006, s164-170). Aslan Gündüz, Uluslararası örgütleri ikiye ayırır. İlk grubun ikinci kadar devlet egemenliğini azaltmadığına vurgu yapar. Birincisi klasik uluslararası örgütlerdir ki, bu kurumlar egemen devletlerin işbirliği esasına göre çalışmaktadır. Ikincisi ise ulus-üstü ya da yarı ulus-üstü örgütlerdir. Bu ulus-üstü örgütlerin temel özellikleri; bir anayasası, kanun-tüzük ya da kurallarının olması, en azından bir unsurunun üyelerini bağlayıcı oy çokluğu gibi bağlayıcı kararlar alabilmesi, kendi kararlarını uygulayabilecek bir mekanizmaya sahip olması, kararlarının sadece kendi üye ülkelerini değil aynı zamanda vatandaşlarını da bağlayıcı olması, kendi yargı organı olmasıdır. Bu özelliklerden birinin ya da ikisinin olmaması bu örgütlerin ulus-üstü karekterini kaybetmesi anlamına gelir (Gündüz, 1991, s107-108). Ulus-üstücülük, kısaca uluslararası örgütlerin hukuki olarak devletlerin ulusal sınırları içinde (AB ve DTÖ) mal, hizmet ve sermayenin dolaşımı üzerinde yetki ve otorite sahibi olmasıdır (Pease, 2012, s87). Aynı şekilde, tarihte ilk olarak Avrupa topluluklarının kurulmasıyla uluslar-üstülük geliştirilmiş; esas olarak kendisini kuran devletlerin, yetkili ulus-üstü hukuk kurumlarının yetkili organlarının hukuksal kararları oybirliği (oydaşma) yerine oyçokluğu ile alması ve bu şekilde üye ülkelerin ulusal hukuklarında doğrudan 
vatandaşları üzerinde haklar ve sorumluluklar doğurmasıdır (Ünal, 2000, s696).

Birçok uluslararası örgüt, uluslararası sistemde faaliyet göstermektedir. Bu örgütlerin bazıları hükümetler-arası, bazıları bölgesel ve bazıları da uluslararası niteliktedir. Bunun yanında, hükümet dışı örgütlenmelere de çokuluslu şirketler, sınır tanımayan doktorlar, Kızıl Haç ve Green Peace’i örnek gösterebiliriz. Bu örgütler yapı ve fonksiyonları açısından birbirinden farklı olabilirler (Pease, 2003, s19).

Magdelana Martinez’e göre bir uluslararası örgütün ulus-üstü özelliği olabilmesi için en az dört özellik gerekir: Dışlayıcı yetkilerinin olması, bağımsız iç organlarının olması, yasa hükmünde bağlayıcı kararlar alarak ve bunları doğrudan üye devletlere ve vatandaşlarına uygulayabilme yeteneği, örgütün aldığı kararları uygulayıcı ve bağlayıcı mekanizmaların varlığının bulunması ve üye devletlerin karşı iradesine rağmen örgütün kendi kararlarını kabul ettirebilmesidir. Avrupa Topluluğu bu özelliklerin bütününü karşılayabilecek kapasiteye sahiptir. Uluslararası örgütler, devletlerin gönüllü olarak egemenlik haklarının bir kısmını yeni bir uluslararası varlık kurmak amacıyla -belirli (ekonomik-siyasi-sosyal) hedefler, şartlar ve zaman dilimine göre- üye devletler tarafından oluşturulmasıdır. Fakat bu egemenlik transferi daima sınırlı karakterde olup üye ülkeler hangi alanlarda örgüte güç ve yetki verdiklerini kararlaştırırlar. AT'de aynı şekilde kendine atıfta bulunulan spesifik konularda yetkilerini kullanır (Martinez, 1996, 99-101).

Vetfalya anlaşmasının metin analizinde devletler karşılıklı olarak birbirlerinin iç işlerine karışmayarak, bağımsız ve otonom oluyorlardı. Birbirleriyle olan ilişkilerinde devlet düzeyinde uluslararası hukukta özne olarak devleti kabul ediyor, birbirlerinin vatandaşlarına karışmıyorlardı (Keyder, 2003, s211). Şimdi bu yapı uluslararası örgütlerin gelişimi ile değişmeye başlamıştır.

Realist John Mearsheimer, uluslararası kurumların bir kurallar bütünü olarak devletlerin birbiriyle işbirliği ve rekabet etme yollarını göstermesinin önemine vurgu yapar. Aynı şekilde bu kurumlar, devletler arasında beklentileri ve uygulamaları belirli kabul edilmiş bir model üzerinden

YIL: 5 SAYI: 10 
tekrarlanan ticaret ve güvenlik gibi her faaliyeti kapsar (Measrheimer, 1993/95, s4).

Birleşmiş Milletler, egemen devletlerin eşitliği ve iç işlerine müdahale etmeme ilkesi üzerinde (Birleşmiş Milletler Kamu Bilgilendirme Ofisi, 1994, s.4) evrensel bir dünya örgütü olarak her yerde barışı ve güvenliği sağlamak için uluslararası bir kurum olarak inşa edildi. John F. Dulles, BM'nin en önemli temel kurumlarından biri olan ve esas karar alma organı olarak inşa edilen Güvenlik Konseyi'nin SSCB'nin vetosu yüzünden etkin olamayacağını ifade eder. Ayrıca komünizmin yayılma tehdidi karşısında; Avrupa ve Amerika' da bölgesel anlamda istikrarı, barışı, uluslararas1 düzeni, liberal hükümetlerin güvenliğini sağlamak için bölgesel kurumlara ihtiyaç doğduğunu belirtir. John, 1947'de Rio Pakt'ının ve 1949'da NATO'nun kurulduğunu söyleyerek bu güvenlik doktrininin mantığının bir üye ülkeye yapılan silahlı saldırının bütün üyelere yapılmış gibi kabul edilmesi olduğunu belirterek ortak savunma yapılacağını söyler (Dulles, 1957, s88-89).

İkinci Dünya Savaşı, Avrupa'nın altyapısını yok etmiş, egemen Avrupa ulus devletlerinin etkin olarak kendilerini savunma yetenek ve güvenlerini kaybettirmiştir. Savaş sonrası süreçte Avrupa'da, farklı işbirliği modelleri içerisinde uluslararası sistemde hükümetler-arası ve ulus-üstü yeni bir kurumsal örgütlenme şekli meydana geldi.

9 Mayıs 1950’de, Fransa Dişişleri Bakanı Robert Schuman, Avrupa Birliği'nin kurucu düşünürü olarak kabul edilen Jean Monnet'in düşüncelerinden etkilenerek hazırlayıp sunduğu Alman ve Fransız kömür ve çelik üretim sektörünü ortak bir 'Yüksek Yönetim' altına almayı tasarlayan örgütlenme modeli ile ilgili bir bildiri yayımlamıştır. Schuman bildirisi, diğer beş Avrupa devleti tarafından kabul edilmiş ve 1951'de altı Avrupa ülkesi Fransa, Almanya, Belçika, Hollanda, Luxemburg ve İtalya Avrupa Kömür Çelik Topluluğunu (AKÇT) kuran Paris Antlaşması imzalamışlardir (Dinan, 1994, s9-10).

AKÇT uluslararası bir antlaşma olmayıp, yapılan ilk uluslar-üstü bir kurum antlaşmasıdır. Uluslar-üstü kurum antlaşmasının anlamı şudur: Taraflar hâkimiyet-egemenlik haklarından bir kısmını AKÇT'ye, yani ulus- 
lar-üstü bir kuruma devretmiştir. AKÇT’nin esas görevleri; üye ülkelerin ekonomik yönden gelişmesi, istihdamın arttırılması ve hayat standartlarının yükseltilmesini sağlamak, kömür ve çelik üretiminin rasyonel dağıl1mını güven altına almak şeklinde özetlenebilir (Tekinalp, 1997, s6).

David Krasner, Vestfalya Barışı'nın modern uluslararası sistemin gelişiminde önemli bir yeri olduğunu ve bu sistemin egemen devletlere kendi coğrafi sınırları içinde etkin bir yetki verdiğini ifade eder. Vestfalyan egemen devlet modelinin dayandığ temel ilkeleri; otonomi, toprak, karş1lıklı tanıma ve kontrol gibi basitçe ifade edebiliriz. Krasner ve uluslararası ilişkiler teorilerine göre özellikle neo-realistler, neo-liberaller, kuramcılar ve kurgusalcılar (constructivist) için devlet egemenliğinin erozyona uğramas1, günümüz dünyasının somut bir gerçekliğidir (Krasner, 2001, s17-42).

Bu bağlamda Avrupa'da bölgesel her Avrupalı ulus devletin tecrübe ettiği, uzun tarihi boyunca yaşadığı kanlı savaşlar, bu devletleri yeni bir yapılanmaya zorlamıştır. Kısaca bu savaşlar; Otuz Yı1 Savaşları, Yedi Y11 Savaşları, Napolyon Savaşları, Almanya-Fansa Savaşı, Birinci Dünya Savaşı ve en yıkıcı olanı II. Dünya Savaşı ve Soğuk Savaştır. Savaş sonrası Avrupa'sında, ekonomik ve siyasi birleşme yolunda önemli üç sebep etkili olmuştur. Avrupa, dünyada güç merkezi olmaktan çıkar ve Avrupa devletleri SSCB ve ABD arasında en az yirmi yıl süren 'iki kutuplu' bir dünyada bu ülkelerin çevresinde yeni bir üçüncü süper güç olmak için ekonomik ve siyasi birleşmeye gitmek zorunda kalır (Sander, 2002, s201). ABD ve SSCB, Doğu ve Batı blokları olarak Avrupa ulus devletleri üzerinde ekonomik, siyasi ve sosyal yönden yeni bir devletler sistemi oluşturmuşlardı (Deporte, 1986, s115-117). İkinci neden Avrupa'da bir daha savaşların ortaya çıkmasını engellemek ve barış bölgesini oluşturmaktır. Üçüncü sebep de Avrupa'nın birleşerek zengin bir yaşam düzeyinin gerçekleştirilmesi için özellikle işsizlik, kalkınma ve gelişmenin sağlanması gibi makro ve mikro ekonomik sorunlarının çözülmesidir. Diğer bir neden de Avrupalı devletlerin birleşmesiyle, uluslararası ilişkilerin düzenli, dengeli ve istikrarlı bir yapılanmaya gitmesidir (Seyidoğlu, 2001, s220-221). Avrupa'da kendi ulus devlet sistemi tecrübesi, özellikle Alman romantik milliyetçiliğinin geldiği evre sonunda oluşan ırkçı, faşist yapı Avrupa'yı dünyada jeopolitik güç dengesinde parçalamıştır. Avrupa devletlerinin uyguladığg

YIL: 5 SAYI: 10 
otarşik, ekonomik ve emperyal siyaset ve yıkıcı rekabet sonrasında, dünya savaşları neticesinde ABD ve Sovyetler Birliği yeni süper güç olmuştu. Dolayısıyla, $\mathrm{AB}$ düzenini neo-realist çerçeveden analiz düzeyine uyumlu yapısal olarak sistemik bağlamda bu şekilde özetleyebiliriz.

Birleşmiş Milletler sistemi 20. yüzyılın ikinci uluslararası kuruluşu idi. Birinci Dünya Savaşı sonrası bir Avrupa örgütü olarak kalan Milletler Cemiyeti'nin başarısızlıklarından ders alan uluslararası toplum, uluslararası alanda barış ve güvenliği sağlamak için yeni bir yapılanmaya girdi. Teorik olarak BM'ye üye ülkelerin 1945'te meşru ulus devlet yapıları -özellikle barıştan ve özgürlükten yana olanların- egemenlik ve bağımsızlıkları ve hukuki eşitlikleri BM anlaşmasını imzalayan 50 ülke arasında resmen tanınmış oldu (Bennett, ve Oliver, 2002, s46-58). Fakat beş büyük daimi üyeye veto hakkı veren Güvenlik Konseyi yapılanması bu eşitlik ilkesine gölge düşürüyordu (Sander, 2002, s.204-205). Pratik olarak bu veto sahibi ülkelerin problemin bir parçası olduğunda örgüt başarısız kalıyor ve uluslararası barış ve istikrar tehdit altına giriyordu. Filistin-İsrail, Irak, Gürcistan, Suriye ve Ukrayna gibi benzeri örnekler BM'nin uluslararası barış ve istikrarı korumadaki rolü ve etkisini zayıflatarak meşruiyet ve reform tartışmalarını sürekli gündemde tutabilir.

Avrupa devletleri, II. Dünya Savaşı sonrasında tekrar böyle bir felaket yaşamamak için hem bu devletlerin kendi kamuoyları hem de yöneticileri, yeni bir oluşum içine girmeleri gerektiğini görmüşlerdi. Avrupa kendi bölgesinde bir örgütlenmeye giderek Avrupa Konseyi, BAB, NATO ve AGITT gibi kurumları uluslararası örgütler olarak tanıdı. Avrupa Topluluğu bu anlamda federasyondan az, kesinlikle hükümetler-arası kurum rejiminden fazla bir yapıdır (Wallace, 1999, s551). AB Entegrasyon sürecinde farklı ulus-devlet egemenliğinden kaynaklanan rejim tartışmaları da gündeme gelmiştir. Çünkü AB'ye üye olacak her ülkenin farklı bir siyasî meşru egemenlik tarihi vardır.

Winston Chuchill, 19 Aralık 1946'da Zürih Üniversitesi'ndeki, 'Avrupa'nın Trajedisi' konuşmasında “Avrupa medeniyetini, kıtayı ve dünyanın geri kalan birçok bölgesini savaştan korumak için mutlaka Avrupa’nın birleşmesi gerektiğini" ifade eder (Reid, 2007, s341). "Küresel sistemde 
BM'nin güçlendirilerek, 'Avrupa Ailesi'nin yeni bir dünya düzeni 'konsepti' içerisinde, bölgesel bazda Birleşmiş Avrupa Devletleri'nin kurulabileceğini; ilk adım olarak da Avrupa Konsey'inin kurulması gerektiğini"” söyler. “Ayrıca Fransa ve Almanya'nın buna öncülük edebileceğini” belirtir (Nelsen ve Stub, 1998, s7-11).

Avrupa devletleri kendi tarihî tecrübeleri sonunda sahip oldukları modern ulus devlet yapılarından vazgeçerek yeni bir bölgesel ulus-üstü yapılanmayla Avrupa'da birliği sağlamak için Entegrasyon sürecini başlatmışlardır. Bu süreç başlangıçta egemen Avrupa ulus devletleri arasında sektörel alanlarda işbirliği şeklinde başlamış, daha sonra farklı sektörlere yayılarak ulus-üstü yapılanmalar oluşturulmuş ve bu, yeni bir hukukî, ekonomik ve siyasî düzen meydana getirmiştir. Dolayısıyla bu gelinen süreçte Avrupa devletleri klasik egemenlik anlayışlarından farklı olarak yeni bir egemenlik anlayışı geliştirmişlerdir.

Bu çerçevede, Avrupa'nın bütünleşme süreciyle birçok siyasal kuramlar geliştirilmiştir. AB kuram ve teorileri, kendi sahası içinde dinamik ve esnek kurguya sahiptir. Kısaca bu kuramları, birleşik devletçilik (federalizm), hükümetler-arasıcılık, işlevselcilik, yeni işlevselcilik, özgürlükçü işlevselcilik ve eş-toplumsalcılık olarak özetleyebiliriz (Çakır, 2001, s1).

Neo-fonksiyonalizm: Karar verme sistemlerinde entegrasyon dinamiklerine odaklanır. Süreçlere dikkati çeker. Belirli entegrasyon eylemleri, entegrasyonun gelişmesinde çok önemlidir. Bu yönüyle dönüştürücü (spillover) hareketlere dikkat çeker. Ancak spesifik entegrasyon eylemleri şayet daha ileri entegrasyon amaçlanıyorsa başarılı olabilirler. Çünkü ekonomik alanlardaki aktiviteler arasında teknik bağlantılar vardır. Entegrasyon gelişerek birçok alanı kapsama eğilimindedir ve siyasal hassasiyeti de uyaran bir yönü vardır. Karar vericilerin geçirmiş olduğu sosyalleşme süreci önemlidir. Çünkü onlar ulus-ötesi karar verme tecrübelerinden yararlanarak dönüştürme (spillover) mantığı yönünde politika belirlerler. $\mathrm{Bu}$ bağlamda farklı ülkelerdeki benzer düşünceleri paylaşanlar arasındaki koalisyon ve işbirliği gelişir. Böylece entegrasyon birçok çıkar gruplarını da sürece katabilir. Fonksiyonalizm de süreci öngörür fakat karar verme gibi detaylarla ilgilenmez; entegrasyonda toplum desteğinin faydacı anlayışa

YIL: 5 SAYI: 10 
evrilme yollarını araştırır ve dönüştürme etkisi (spillover effect) üzerine odaklanır. Ortak kurumlarla birlikte çalışmanın toplumsal düzeyde siyasal topluluğun oluşmasında büyük katkısı vardır. Bu topluluk içerisinde çal1şan bir barış sistemi vardır. Savaş çıkma olasılığı azdır, çünkü fonksiyonel işbirliği vardır. Toplumsal destek daha ileri entegrasyon ve daha fazla ortak kurumlar için baskı oluşturur. Böylece siyasal topluluk için toplumsal desteği artırır, buna da entegrasyon dinamiği denir. Şekil fonksiyonu izler. Her bir konu bu yaklaşımla bu düzeyde, esas konuya en uygun tavır ve yolla ele alınmalıdır (Çakır, 2001, ss.1-63).

AB entegrasyonunun devletçi ve federal yaklaşımlarla, 1950'lerde hem ekonomik hem de siyasî nedenlerle Avrupa ülkelerinin pragmatik şekilde kendi egemenliklerini sınırlayarak AB'nin ortak topluluk kurumlarını yetkilendirdiğini Adalet Divanı'nın 1964 tarihli Dava 6/4 ECR 1159 sayılı kararıyla savunur. Bunun yanında Topluluk sistemi, fonksiyonalist teori, uluslararası rejim teorisi ve İş-birlikçi federalizm yaklaşımlarıyla, AB sürecini teorik boyutta açıklamaya çalışır (Vandamme, 2998, s143).

Federalizm, farklılık sorunlarına anayasal bir çözümün gerekliliği üzerinde durur. Bu yönüyle kurucu meclisin önemine sıkça vurgu yapar. Lider siyasetçilerden oluşan bir forumda, yüksek düzeyde ve kurucu unsurlar arasında anayasal bir güçler ayrımı anlaşmasını öngörür. Entegrasyonun önemli ani bir hareketle gerçekleşeceğini savunur. Kurucu bölgeler arasındaki farklılık, anayasanın hazırlanmasına sorun çıkarsa da önemli bir mesele değildir. Çünkü birimler ve birlik, her biri kendi inşa edilmiş alanlarında egemendir. Federal hükümet egemenlik kazanmıştır. Bu hükümet birlik adına dış ilişkilerde minimum düzeyde hareket eder. Merkezde normal karar verme modu oy çokluğu ile gerçekleşir. Anayasal düzeyde birlik ve birimler arasında güçler dengesi vardır. Modern federasyonlar birimler arasındaki farklı alanlarda yatay işbölümüne açıktır. Ayrıca farklı birimlerin federal hükümette orantılı (nispi) temsili sınırlıdır. Ayrıca genel çıkarların geliştirilmesi için kapsamlı ortak düzenlemeler vardır (Taylor, 1945, s290-291). Eş-toplumsalcılık: Birimler yüksek düzeyde bir otonomiye sahiptir. Ortaklıkta birimlerin otonomileri korunmuştur. Birimlerin ve kolektif refah ve çıkarın artırılması için ortak düzenlemeler yapılır. Genel çıkarı geliştirmek için değerler ortak düzenlemelere bağlı olarak 
bağımsız değiş̧kenler şeklinde gösterilir. Ortak hükümette bir elitler karteli etkin olarak yönetir. Bu kartelde elitler kararlarını oybirliği ile alır. Burada çoğulculuk yoktur. Birimler merkezde kesin bir temsil orantısı içinde temsil edilir. Egemenlik merkeze transfer edilmemiştir. Seçkinler birimlerin otonomilerini koruma yollarını araştırırlar. Hükümetlerarasılık: Kaba şekliyle, devletler şartsız olarak kendi önceliklerini bu sistemde korumaya devam ederler. Böylece ortak düzenlemeler önemsizmiş gibi görülür. Daha yumuşak ifadeyle, devletler kendi önceliklerini sürdürürler ve devletler uyum araçlarını ve varlıklarını korumak amacıyla modern dünyada ortak düzenlemeleri gerekli görürler. Bu yönüyle ortak düzenlemeler, bağımlı bir değişken olarak devletin çıkarına hizmet ettikçe var olacaktır (Çakır, 2001, ss.1-63).

$\mathrm{Bu}$ entegrasyon ilk etepta, Fonksiyonalist teorinin öngörüsüyle David Mitrany'nin 'Çalışan Barış Sistemi' (1943) Avrupa devletleri arasında gelecek savaşları önlemek için uluslararası ilişkiler alanında insanların düşünüş şekillerinin dönüştürülmesi gerektiğini savunur. Mitrany'nin fonksiyonel alternatifi, Avrupa'nın birliği değil dünya barışını öngörmüştü. Fakat daha sonraki entegrasyon teorisyenlerinden Jean Monnet ve Neo-fonksiyonalizmi savunanları oldukça etkilemiştir. Mitrany'e göre uluslararası çatışmaların temel sebebi rekabet eden farklı, bölünmüş politik birimlerdir. Dünyaya barışı federal hükümetler getirebilir; fakat devletlerin anayasaları, paktlar ve milliyetçilik bunu imkânsız kılmaktadır. Fonksiyonel yaklaşım, politik farklılıkları örterek ya da görmezlikten gelerek uluslararası aktiviteler ve kurumlarla ağlarını genişleterek, milletlerin yaşamsal çıkar ve menfaatlerini tedrici olarak birleştirecektir. Fonksiyonel entegrasyon faydacı, teknokrat ve esnek olacaktır. Bilinçli bir şekilde millî ile uluslararası, kamu ile özel ve siyasî ile siyasî olmayan arasındaki sınır belirsizleşecektir. Fonksiyonel entegrasyon kurulduktan sonra millî sınırların önemi azalacaktır. Bu süreç sonunda merkezî yönetimler bu farklı kurumları koordine edebilir duruma gelecek ancak yeni bir merkezî hükümete gerek olmayacaktır. Mitrany, bu bağlamda diğer Fonksiyonalist ve Neo-Fonksiyonalizm savunucularından farklı düşünür (Nelsen ve Stub, 1994, s77-97) Fonksiyonalistler devlet egemenliğinin uluslararası ilişkilerde dirençli olmasının farkında olarak entegrasyonu sosyal ve ekonomik

YIL: 5 SAYI: 10 
alanlarda sürece yayarak işbirliğini hükümetler-arası, sivil ve çokuluslu şirketler aracılığıyla kurumsallaştırarak ulus-üstü kurumların ulus devletlerin yerini alabileceğini, düşünür (Pease, 2012, ss.66-69). Bu yönüyle fonksiyonalistler normatif bir uluslararası düzen öngörmektedirler.

Jean Monnet, 'değişimin mayası' şeklinde ifade edilen yeni bir devletler-arası ilişkiden yeni bir Avrupa'nın yaratılması ihtiyacı oluştuğuna değinir. Burada en büyük sorun, yaklaşık üç yüzyıl tarihî bir birikim üzerine oturtulmuş Avrupa devletinin ulusal siyasî, ekonomik, sosyal ve kültürel kimliğini oluşturduğu, modern bir ulus devlet yapısıdır ki; bu yapı bütün Avrupa devletlerinin anayasal yapılanmalarını da yeniden inşa etmelerini gerektirmiştir (Gözler, 2000, s25-46). Bunun sonucu olarak da Avrupa entegrasyonunun başarılması için farklı Avrupa ulus devlet egemenlik siyasalarını ve karşılaşılan zorlukları aşmak ya da ifade etmek için birçok yeni kavramsallaştırma ihtiyacı doğmuştur. Bu da ancak klasik ulusal ve uluslararası hukuku aşan yeni bir hukuk sistemi ile gerçekleşebilir.

\section{AB Hukuk Düzeninin Temel Özellikleri}

Avrupa'da hiçbir hükümet, yüzyıl önceki diplomat ve anayasa hukukçularının yorumladığı anlamda egemenlik anlayışına sahip değildir. 1995 sonrası on beş üyeli AB'de karşılıklı olarak birbirlerinin iç sorunlarına müdahale, geniş kabul gören bir pratik haline gelmiştir. AB'nin kendi s1nırları dışında kalan (extra-territorial) yargısal anlamda da üyesi olmayan Norveç, İzlanda ve İsviçre gibi ülkeler, ekonomik ve sosyal alanlarda da AB'ye bağımlı oldukları için AB'nin kurallarını kabul etmişlerdir. AB'nin güvenliğini NATO ortak karar mekanizması içinde çokuluslu askerî birimler sağlamaktadır. AGİT çerçevesinde Avrupa'nın güvenliği, AKKA prosedüründe belirlenen şeffaf kurallar içerisinde yürütülür. AB yapılanmasında birçok meşru kurumsal örgüt oluşturulmasına rağmen hâlâ etkin olan birimler devletlerdir (Wallace, 1999, s503).

Fakat bunun yanında McGoldrick’e göre AB, küresel uluslararası ilişkiler arenasında çok önemli bir varlık olarak ortaya çıkmıştır. AB, dünyanın diğer ülke ve bölgeleriyle, ekonomik örgütlenmesiyle birlikte, siyasal ilişkilerinde daha kapsamlı bir yaklaşım geliştirmiştir. AB, uluslararası 
arenada kendi üye ülkelerinin var olan geleneksel kolonyal dönemden kalma ilişkilerini modern zeminde sürdürmesinin yanında, kurumsal olarak da hukukî kişilik, düzen ve yetki şeklinde de kendini kabul ettirmiştir. $\mathrm{Bu}$ ifadelerden açıkça $\mathrm{AT}$ ve $\mathrm{AB}$, uluslararası düzende bir hukukî kişilik kazanmanın verdiği bütün hakları (anlaşma yapma yetkisi, uluslararası örgütlere üye olma, toplantılarına katılma, diplomatik tanınma, uluslararası sorumluluk gibi) kullanabildiği gibi, kendi kurumlarının ve Avrupa Adalet Divanı'nın öngördüğü şekilde uluslararası hukukun tanıdığı birçok haklar1 kullanma yetkisine de sahiptir (McGoldrick, 1997, s26-78). Bu durum AB'nin ortak dış ve güvenlik politikasını belirleme sürecinde, AT'de olduğu gibi, klasik kullanımda ikinci ve üçüncü sütunlarda ulus-üstü seviyeye çıkma çabaları, AB'nin uluslararası arenada siyasî ve askerî bir güç olarak da prestijini yükseltecektir. AB'nin ekonomik ve sosyal sahadaki yumuşak güç başarısını siyasî ve askerî alana da kaydırmak istemektedir. Bu sebeple Bosna, Makedonya, Kosova, Kongo ve Çad'a, BM ya da NATO altında barış gücü yerleştirmesi, İran nükleer görüşmeleri, Ukrayna'nın toprak bütünlüğünü korumak için Rusya'ya yaptırım uygulanması vb. onun bir siyasa modeli olarak kendisini göstermek şeklinde de anlaşılabilir.

$\mathrm{AB}$ hukuku ya da topluluk hukuku olarak anılan hukuk düzeni, üç Avrupa Topluluğu'nun (Avrupa Ekonomik Topluluğu, Avrupa Kömür ve Çelik Topluluğu, Avrupa Atom Enerjisi Topluluğu) hukukudur. Bu hukuk düzeni üç topluluğun kuruluşuna, işleyişine, organlarına, düzenlediği ortak pazara ve öteki toplulukların politikalarına ait kurallar ile toplulukların üye devletlerine ve üye olmayan üçüncü devletlerle ilişkilerine ait kuralları içermektedir. AB hukukunun temelini, birincil hukuk diye anılan Avrupa Topluluğunun kurucu antlaşmaları ve bunların tamamlayıcısı öteki antlaşmalar (1951 Paris AKÇT Antlaşması, 1957 AET Antlaşması, 1986 Avrupa Tek Senedi, 1992 Maastricht Antlaşması, 1997 Amsterdam Antlaşması (Bozkurt, 2001, s14-48), Nice ve Lizbon Anlaşmaları) ve ekleri oluşturmaktadır. AB hukukunun ikincil önemli kaynağı ise İkincil hukuk diye anılan AB organlarının hukuksal eylemleridir. ATAD'ın içtihadı, AB hukukunun hem uluslararası hukuk hem de üye devletler iç hukuklarından özerk bir hukuk düzeni oluşturduğunu ve bu hukukun yukarıda adı geçen antlaşmalar aracılığıyla konulan kuralların hem üye devletleri, hem

YIL: 5 SAYI: 10 
AB organlarını, hem de yöneltildikleri bireyleri ve iç hukuk tüzel kişilerini doğrudan bağladığını kabul etmektedir (Tekinalp, 2000, s66). Avrupa Topluluklarının her birinin taraf oldukları anlaşmalar hem AB organlarını hem $\mathrm{AB}$ üyesi devletleri hem de ilgili oldukları bireyleri, kurumları ve firmaları ya da iç hukuk tüzel kişilerini doğrudan bağlamakta ve onları birer hukuksal kişilik olarak tanımaktadır. Ayrıca Avrupa Topluluklarının her biri uluslararası hukuk kişiliğine sahip olduğu için anlaşma yapma yetkisi yanında, üçüncü devletler ve öteki uluslararası örgütlerle temsil ilişkileri kurma ve yürütme yetkisine de sahip bulunmaktadır. $A B$ hukuku bir çelişki durumunda, üye devletler iç hukuklarına üstün gelmektedir. $\mathrm{AB}$ hukukunun belirtilen bütün bu özellikleri, bu hukuk düzenini ulus-üstü bir hukuk düzeni yapmaktadır. Dolayısıyla AB hukuku uluslararası hukuktan da üç yönden farklılık gösterir: $\mathrm{AB}$ hukuk düzeninde kurallar, kurucu anlaşmalar yanında $\mathrm{AB}$ organlarınca da koyulmaktadır. Ayrıca bireyler ve iç hukuk kişileri de doğrudan $\mathrm{AB}$ kurallarıyla bağlanmış, haklar ve hukuki yetkilere sahip olmuştur. Son olarak ATAD'ın varlığı ve yaptırım gücü, aldığı kararların $\mathrm{AB}$ organlarınca ya da üye devletlerce uygulanmasını sağlayacak bir mekanizmaya sahip olmasındandır (Pazarcı,2007, s10-11).

Avrupa Birliği hukukunu oluşturan birçok özellik vardır. Avrupa Topluluğunun üye ülkelerdeki yasalarla eşdeğer güçte düzenlemeler yapabilmesi özerklik ilkesinin; Avrupa Topluluk hukukunun, üye ülkelerde ve üye ülkelerin vatandaşlarının aynı zamanda Avrupa Birliğinin vatandaşı olarak nitelendirilmesi nedeniyle doğrudan uygulanabilirlik ilkesinin; üye ülke hukukundaki düzenlemenin topluluk hukuku ile çelişmesi durumunda, topluluk hukukunun üstünlüğünün söz konusu olmasıdır.

Özerklik, doğrudan uygulanabilirlik ve üstünlük ilkeleri yalnızca Avrupa Topluluğu'na özgüdür. Bunlar programlar ve deklarasyonlardan oluşmakta, hükümetler-arası işbirliği ile uygulamaya dönüştürülmektedir. Burada elbette devletin sorumlulukları ve ulusal mahkemelerin rolleri de vardır (Kennedy, 1998, s143-151).

Direk etki ve üstünlük ilkesi, $A B$ sisteminin anayasal saç ayağı gibi kabul edilmektedir. Çünkü Adalet Divanı bireyleri AB'yi uluslararası hukukta hukuki bir taraf kabul ederek antlaşma hukuku ile ulusal hukuk ara- 


\section{$76 \cdot$ YALOVA SOSYAL BILIMLER DERGiSi}

sındaki belirsizliği kaldırmaktadır. Dolayısıyla ulus-ötesi hukuk alanında bireyler için ulusal mahkemelerin üstünde haklarını arayabilecekleri bir topluluk hukuku vardır. Diğer yandan Adalet Divanı yargı kararlarının uyumlaştırılması ve ulusal yasamalar arasındaki farklı hukuksal yorumları Avrupa'da bir standart oluşturmak için birleştirmesi gerekecektir. Kısaca ulusalı aşan ve hükümetler-ötesi hukuki süreçte ulusal düzenin otorite yapısı, başka bir düzeyde sorgulanır hale gelecektir. Burada sorun büyük bir devletin yaratılması değil, ulusal ve dış otorite ilişkilerinin birbiriyle karıştırılarak spesifik konularda farklı otoritelerin kabul edilmesidir. Dolayısıyla belirli alanlarda özerkleşirken, fizikî devlet sınırlarının otoritelerinin gevşetilmesi bizi Vestfalya devletinden uzaklaştırmaktadır (Caporaso, 2000, s17-18).

Avrupa bütünleşmesi temel anlaşmalar (Paris, Roma, Maastrict, Amsterdam, Nice ve Lizbon) üzerinde değişiklikler yapılarak inşa edilmiştir. Topluluk antlaşmaları, "Âkit devletler" arasında, sıradan antlaşmalardan daha ötede yükümlülükler getirmekte, egemenlik bahşeden organlar kurmakta ve bunların yetkisi/gücü bireyleri ve üye devletleri etkilemektedir. Temel değişim, bu organların üye devletlerin hukuk sisteminin ayrılmaz bir parçası haline gelerek kendi hukuk sistemlerini meydana getirmesidir. Topluluk hukuku, bireylere, hem ulusal hem de AB mahkemelerinde, devletlere ve diğer kurum, kişi ve aktörlere karşı ileri sürülebilen haklar ve sorumluluklar yükleyebilmektedir. AT'nin 189. maddesine göre antlaşmalardan başka tüzük, yönerge, karar, tavsiye ve görüş gibi diğer değerli kaynaklarının yanında topluluğun üçüncü devletlerle ve uluslararası örgütlerle yapmış olduğu antlaşmalar da hukuki kaynaklarını meydana getirmektedir. Ayrıca Adalet Divanı'nın kararları topluluğun en önemli kaynağını oluşturmaktadır (Zararsız, 2000, s713).

$\mathrm{AB}$ hukuku uluslararası hukuktan uluslar-üstü hukuk yönüyle üye devletlerin bir onayına bağlı kalmadan doğrudan $A B$ kurumlarını, üye devletleri, tüzel kişi ve bireyleri resmi gazetede duyurulması ile bağlamaktadır. Bu uluslar-üstü hukukun temel özellikleri aşağıda özetlenmiştir (Ünal, 2000, ss.697-698):

YIL: 5 SAYI: 10 
Avrupa vatandaşlı̆̆l, AB Ombudsmanına başvurma hakkı, $A B$ yasama konseyinin oyçokluğu ile karar verebilmesi, AB parlamentosunun direk $A B$ vatandaşlarınca seçilmesi ve siyasî grupların olması, AB Adalet Divanı zorunlu yargl yetkisinin kabul edilmesi, AB üyesi devletin Birlik hukukundan kaynaklanan yükümlülügü̈nü yerine getirmemesi durumunda para cezası kesebilmesi, ön karar prosedürünün olmasl, Birlik hukukunda genel kapsamlı tüm yönleriyle bağlayıcı, üye devletlerde doğrudan uygulanan ve vatandaşlarına bile doğrudan hak ve yükümlülükler getirebilen tüzük gibi hukuksal normların olmasl, AT Konsey-Komisyon ve Mahkemenin parasal yükümlülük getiren cebri icra ilamı özelliği olmasl, AB'yi kuran anlaşmaların sınırsız bir süre için akdedilmesi, toplulukların üçüncü ülkelerle yaptığg anlaşmaların AB'ye daha sonra katılan ülkeleri bağlamasi.

Burada Avrupa'nın ulaştığı entegrasyonun boyutu, geleneksel ulus devletlerin kontrol ettikleri alanın çok ilerisine gitmiş olmasıdır. Bu anlamda üye devletler arasındaki engeller oldukça zayıflamış ve yerel hükümetler ve şirketler arasındaki bağlantılar güçlenmiş; bu durum Avrupa kıtasında giderek yeni uluslararası sınırları oluşturmuştur. Bu anlamda bu süreç, kendi içinde çoktan uluslararası aktivite boyutunu aşmış, AB programları sınırlar-arası ve bölgeler arası işbirliğini geliştirmiştir. Ekonomik ve finansal krizlerin tetiklediği sosyal sorunları aşacak AB düzeyinde Avrupa toplumunu inşa etmek için ciddi dayanışma politikaları belirlemektedir. $\mathrm{AB}$, uluslararası hukukun ürettiği bir yapı olarak uluslararası alanda bir aktör olmuş ve yeni bir uluslararası hukuk yapım sürecini kendi bölgesi dışındaki kıtalarda da bu süreci serbest ticaret bölgesi şeklinde başlatmiştır (Murphy, 1999, s240-241).

Miriam Aziz, hukuku geleneksel olarak hiyerarşik bir normatif düzen olarak aktarır. Almanya örneğinde bu hiyerarşi temel yasa, federal yasa ve devlet yasalarıdır. Avrupa Topluluğu hukukunun da ulusal hukuk üzerinde birincil ve ikincil hukuk kaynakları şeklinde hiyerarşik bir üstünlüğü vardır (Lasok ve Lasok, 1994, ss103-175). Bu durumun Avrupa egemen 
ulus devlet sistemine önemli etkisi vardır. Çünkü AB hukuku geleneksel egemen devletlerin yetki alanına giren birçok konuyu, üye devletlerin özerk alanından alarak Avrupalılaşma yolunda sorumluluk ve yetkilerini havuzlayarak paylaşmaktadır. Avrupa Birliği elbette makro küreselleşme sürecinde ulus devlet egemenliğinin sonu gibi tartışmalara ve kaygılara dünyada kendine has mikro düzeyde bölgesel çerçevede yeni bir çözüm sunmuştur. $\mathrm{Bu} A \mathrm{~B}$ yapılanması, bir siyasa olarak nitelendirilmiş ve AB'ye üye devletlerin egemenliği belirli bir hukukî, ekonomik, siyasal ve sosyal alanda entegrasyon sonucunda evrimleşmiş bir form haline gelmiştir. $\mathrm{Bu}$ süreçte devletin nicel ve niteliği gelişerek mikro ve makro alanda birçok somut altyapı, standart, şart, kurallar ve koşullara sahip olan devletin üyeliği kabul edilmektedir (Aziz, 2001, s3). AB yapılanması elbette çok kolay basit sistematik bir düzene sahip ulus devlet örneği gibi şekillenmiş bir siyasa değildir. Mesela AB'nin ulus-üstü ortak pazarına Almanya'ya ithal edilen muzla ilgili bir davada, ATAD, hem hiç muz üretmeyen Alman tüketicilerinin hakkını koruyacak hem $\mathrm{AB}$ üyesi ülkelerin denizaşırı topraklarında üretilen muzlara $\mathrm{CE}$ ayrıcalıklarını gözetecek hem de AB'nin Karayip ülkeleriyle yapmış olduğu özel antlaşmalara sadık kalacaktır. Bunun yanında $\mathrm{ABD}$, üçüncü ülkeler ve GATT prensiplerini de dikkate alacaktır. Görüldüğü üzere $\mathrm{AB}$ içerisinde her bir konu ya da ürün çok karmaşık dava ve olaylara sebep olabilir. Dolayısıyla, küresel sistemde, AB'nin kendi varlığını sürdürebilmesi için AT üyelerinin çıkarlarını olabildiğince maksimize edebilmesi gerekmektedir. Bu da, ancak AB'nin yönetişim anlayışını, sorunun tarafları ve uygulayıcısı bağlamında çok katmanlı olmas1, hiyerarşik olmayan bir çerçeveye de oturtur.

Ayrıca Avrupa devletleri ulusal hukuklarını insan hakları konusunda Avrupa Konseyi İnsan Hakları Mahkemesine, AT hukukuna, AB hukukuna ve Avrupa Ekonomik Alanı hukukuna uyumlu hale getirmek zorundadirlar (Kennedy, 1998, s137-164).

Jürgen Habermas, uluslararası toplumun, millî devletin güçlendirilmesi dişında devletin sosyal devletten soyundurularak -demokratik meşruluk zedelenmediği müddetçe- millî devletin işlevlerini ikame edebilecek niteliklere sahip, daha büyük siyasî birimlere ve milletler-üstü rejimlere doğru bir arayış olduğunu söyler. Millî devletin ötesinde kurulabilecek

YIL: 5 SAYI: 10 
bir demokrasinin ilk örneğini Avrupa Birliği oluşturacaktır. Fakat Habermas, siyasetin henüz tam olarak demokratik meşruiyet zemininde, küresel ve bölgesel ölçekte, piyasanın önüne geçemediğini söyler. Çünkü kendi çıkarlarını koruma siyaseti izleyen ekonomik aktörlerin siyasal aktörlerden farklı olarak bir demokrasi kaygisı yoktur (Habermas, 2002, s36-37). Örneğin $\mathrm{AB}$ üyesi ülkeler arasındaki ticaret $\% 70$ 'den fazla olmasına rağmen $\mathrm{AB}$ vatandaşlarının birlik içinde hareketliliği \%1.5 gibi çok düşük bir oranda kalmaktadır. $\mathrm{Bu}$ ise bize ulus devlet milliyetçiliği, yabancı düşmanlığı, aşırılıklar konusunda hoşgörü ve çok-kültürlülük konularında AB'nin başarılı olamadığını göstermektedir. Dolayısıyla, entegrasyon mantı̆̆ içinde $\mathrm{AB}$ ulus devletler arasında ortak bir ekonomi, mali, para, güvenlik ve dış politika gibi konularda stratejik işbirliği, hükümetler-arasıcılık, ulus-üstücülük ve yönetişim yaklaşımlarıyla tam olarak Avrupa aidiyetini oluşturamadan kıtasal bir devlet hukukunu oluşturmanın zor, uzun ve ucu açık bir entegrasyon süreci olduğunu hatırlatmaktadır.

$\mathrm{Bu}$, tek bir birlik oluşturmak için çok kapsamlı ve çok yönlü disiplinler-ötesi yaklaşımlara ihtiyacı doğuran bir süreç başlatmıştır. Bu süreç şüphesiz nihai amaç olarak Avrupa'da yeni tek bir siyasa yapılandırılmas1 gerçekleştiğinde, Westphalia-sonrası egemen ulus devlet sisteminden farklı uluslararası sistemde yeni bir düzen ortaya çıkarmış olacaktır. Bu Avrupa Birliği'nin Entegrasyon süreciyle ilgili yapısal, sistemsel, kurumsal, ulusal ya da yerel birçok alanda uluslararası ilişkilerin temel yapı taşı olan devletler sisteminin de hukuksal değişimi ve dönüşümünü, evrensel ve bölgesel-kıtasal boyutta yeni bir uluslararası devlet formunu meydana getirmektedir (Caporaso, 1996, s1). Avrupa Birliği kendi içinde çok kapsamlı birçok teorik yaklaşımların gelişmesine katkı sağladığından uluslararası ilişkilerin gelişimine de büyük katkısı vardır. Entegrasyon süreci, Leon Lindberg' in kullandığı anlamda, uluslararası ilişkilerde analiz düzeyinde Avrupa Birliği bağlamında sistemsel değişimde, devlet ilişkilerinde ve siyasal bireyin davranışlarında yeniden yapılanma, tanımlama, ulusal kimlik, aidiyet ve sadakat gibi sorunları çıkarır (Pentland, 193, s13-25). Bu yönüyle Avrupa Birliği'nde ve üye ülkelerde hukuksal bağlamda egemenlik tartı̧̧malarının nasıl olduğuna dair kavramsal ve teorik katkı konumuzun somut anlaşılmasını kolaylaştıracaktır. 
80 - YALOVA SOSYAL BILIMLLER DERGISI

\section{AB'de Egemenliğin Yeniden Yapılandırılması}

Simon Hix'e göre Avrupa Birliği çok önemli bir başarıdır. Hix, AB sistemini bir devletten ziyade bir siyasal sistem olarak tanımlar. AB, egemen Avrupa ulus devletlerinin gönüllü olarak ekonomik, siyasî, sosyal ve kültürel alanda başlattığı bir süreçtir. $A B$ bu süreci, kömür ve çelikten başlayarak ekonomik, sosyal ve siyasal birliği de kapsayacak şekilde altı devletten, 90'larda 15 devlete 2004'te 25'e, 2007'te 27'ye, 2013'te 28'e çıkarmıştır. AB'ye ileriki dönemlerde 5 ya da 10 yeni üye devlet daha katılabilir. Avrupa Entegrasyonu, Avrupa düzeyinde kendini yöneten çok önemli kurumsal otorite ve politikalar üreten yapılanmalara sahiptir (Hix, 2005, s1).

Fakat bununla birlikte AB'de anayasal tartışmaların içinde devletçi (etatism) ve devlet sonrası (post-etatism) yaklaşımlar vardır. İlk görüşe göre AB bir anayasaya sahip değildir; çünkü bir devlet değildir. Devlet, anayasa için bir ön koşul olmuştur. İkinci görüş ise bir anayasanın ön şartı için siyasal bir topluluğa ihtiyaç olduğunu, devletin böylece anayasasında siyasal sisteminin dayandığı bir hukuki düzenden oluşması gerektiğini savunur. Her ikisi de farklı egemenlik anlayışına sahiptir. İlk görüş hukukî egemenliği ulus devlete dayandırır. AB'nin ulus-üstü ya da hükümetler-arası form ve mekanizmasıyla ancak ulus devletin çıkarlarını ve temel haklarını geliştirmesi oranında meşruiyetini sürdüreceğini düşünür. İkinci görüş ise kozmopolit bir egemenlik-sonrası (post-sovereignty) yaklaşımı öngörür. Bu anlayış Avrupa halklarını, kültür ya da toprak temeli üzerine değil ulus-ötesi bir hukuk sisteminde ve devlet-ötesi ilkeler üzerine inşa etmiştir (Aziz, 2001, s4-5).

$\mathrm{AB}$ ülkeleri Maastrict Anlaşması sonucunda anayasalarında egemenlik bağlamında bir takım değişikliklere gitmişlerdir. Egemenlik ulusundur anlayışından $\mathrm{AB}$ ölçeğinde egemenliğin paylaşılabileceğini kabullenmişlerdir. Bu süreçte AB ülkelerinin bazıları aşağıdaki şekilde anayasalarında egemenlik konusundaki yaklaşımlarını belirlemişlerdir.

Almanya Anayasası'nda madde 24: "Federasyon, devletlerarası kurumlara egemen haklar devredebilir.”; Italyan Anayasası 'nda madde 11: "Italya öteki devletlerle karşılıklılık ilkesini gözeterek,

YIL: 5 SAYI: 10 
AVRUPA BÜTÜNLEŞMESI SÜRECINDE: HUKUK, DEVLET VE EGEMENLIK,,,' 81

devletlerarasında barış ve adaleti sağlayan bir düzen için gerekli gördüğ̈̈ egemenlik haklarının sinırlandırlmasını kabul eder."; Belçika Anayasası madde 25: "Belli yetkilerin kullanılması bir anlaşma ya da bir yasa ile devletler hukuku kurumlarına terk edilebilir.”; Lüksemburg Anayasası madde 49: "Yasama, yürütme, yargl yetkileri uluslararası örgütlere devredilebilir."; Hollanda Anayasası madde 92: "Yasama, yürütme ve yargı yetkileri, bir sözleşme ile uluslararası kamu kuruluşlarına devredilebilir.”; Yunanistan Anayasası madde 28: “Yunanistan'ın taraf olduğu uluslararası sözleşmeler iç hukuktan üstündür ve bir iç yasa hükmü ile çatışma halinde uluslararası sözleşmeler uygulanır. Bir uluslararası antlaşma ile ulusal kurumların anayasada belirtilen yetkileri uluslararası kuruluşlara devredilebilir." (Oder, 2000, s119-190)

Diğer üye ülkelerde de buna benzer açıklamalar bulunmaktadır. Ayrıca bazı ülkeler klasik uluslararası örgüt üyeliği ile AB üyeliği arasında fark gözeterek egemenlik transferi gibi konularda ayrı bir yaklaşım sergilemişlerdir.

Çek Cumhurbaşkanı Vaclav Havel, Avrupa Birliği'ne entegrasyon sürecinde nasıl bir yapıya entegre olunduğunun bilincinde olarak ulusal egemenlik konusunda sergilediği yaklaşımı şöyle ifade eder:

"Evet, biz isteyerek mutlu bir şekilde egemenliğimizin bir kismindan Avrupa Birliği'nin ortak idare edilen egemenliğine feragat ediyoruz. Çünkü biz bütün Avrupalıların bildiği gibi çok daha fazlasını, karşılığında alacă̆ız. Dünyanın bir parçasında yaşadığımız bu bölgede, biz artık sürekli savaşan idarecilerin, güçlerin, milletlerin, sosyal sinıf ve dinî doktrinlerin, toprak ve hegemonya için mücadeleci rekabet ve etkilerden uzak bir arena olarak büyük değişim ve dönüşüm yaşadığını görebiliyoruz. Bir arada yaşayan insanlarımız arasında gerçekçi bir diyalog ve etkili bir işbirliği içinde ortak olarak paylaştığımız, ortak olarak idare ettiğimiz, ortak olarak oluşturduğumuz alandan birlikte yaşamaya ve dayanışmaya kendimizi adadık." (IEA , 2001, s2) 
Batı Avrupa ülkelerinin başlatmış olduğu Avrupa Entegrasyon sürecinde, ulus devletin ötesinde AB eksenli tam egemenlik anlayışı, federatif sistem gibi farklı siyasal kurgulamalar bağlamında yoğun olarak tartışılmaktadır (İyibozkurt, 2000, s138). Egemenlik ekseninde AB kendi içinde birçok yeni kavramsal çerçeveler, konsept ya da karmaşık semboller oluşturmuştur. Kısaca bu yeni Avrupa entegrasyonu çerçevesinde ulusal ya da millî devlet kavramlarıyla birlikte kullanılan egemenlik kavramının önüne ya da arkasına birçok yeni sıfat ve isimler ekleyebiliriz. Egemenliğin paylaşımı (Wallace, 1999, s503-521), egemenliğin havuzlanması (Peterson,1997, ss559-578), egemenliğin ortak kullanımı, egemenliğin ikame edilmesi, egemenliğin bölünmesi, egemenliğin transfer edilmesi, egemenliğin dönüşümü, egemenliğin sınırlandırılması, egemenliğin önemini kaybetmesi (Romero,2004), ulus-üstü egemenlik, ulus-ötesi egemenlik, bölgesel egemenlik, egemenlik-ötesi ve egemenlik-üstü gibi yeni kavramlar da üretilmekte ve akademik çalışmalarda yaygın olarak kullanılmaktadır. $\mathrm{Bu}$ bağlamda geleneksel ulus devlet egemenlik anlayışında, Avrupa ulus devletlerinin anayasaları egemenliğin kaynağı ve kullanılmasının çerçevesini belirlemiştir. Fakat Jean Bodin'den bu yana klasik modern ulus devlet egemenliğini toprak merkezli, spesifik bir siyasî ulusa (etnik-sivik) atfen bölünmez, bütündür, devredilemez, paylaşılamaz şeklinde gelenekselleşmiş bir anlayış hakimdir.

Avrupa Birliği, hem genişleme hem de ekonomik bütünleşme sürecini büyük ölçüde başarıyla sürdürmesi ile AB'nin Avrupa'yı birleştirme amacı günümüzde küreselleşmenin ortaya çıkardığı karmaşayı önleyecek, bunun yanında da, ulus devletin kurumsal baskısını azaltacaktır. Bununla birlikte AB'yi hukuksal ve siyasal olarak 21. yüzyıla hazırlamak için AB'de karar alma mekanizmalarının ve kurumsal işleyişin yeniden yapılandırılması gerekecektir (Öz, 2005, s57-82). Lizbon Anlaşması da bu değişimi, federal ve anayasa gibi devleti çağrıştıran ifadelerden kaçınarak ince bir diplomasi ile, büyük AB Başkanlığı, AB'nin Dış Politika Yüksek Temsilciliği, Konsey'de nitelikli çoğunlukla kararların alınması, Komisyonun Komiser sayısının 2/3 üye oranına düşürülmesi, AB Parlamento üye sayısının 751 'de sınırlandırılması gibi büyük oranda gerçekleştirmiştir.

YIL: 5 SAYI: 10 
AB'de hukuk, egemenlik ve devlet tartışmaları genelde iç içedir. Dolayısıyla burada AB'de devlet ve benzeri tanım, kavram, sıfat ve isimlendirme tartışmalarının hangi bağlamda ve hukukî, siyasî terimlerin nasıl ele alındığını inceleyeceğiz.

\section{AB'de Devlet Eksenli Tartışmalar ve Bütünleşme Sürecine Eleştirel Bakış}

Avrupa Birliği hakkında uluslararası örgüt, uluslararası hukuk, üniter, ulusal, kıtasal, bölgesel, federal ya da kon-federal devlet benzeri birçok karşılaştırmalar yapılmaktadır. Ancak AB bu benzetmeler içerisinde jeo-politik, siyasî, hukukî, ekonomik ve sosyo-kültürel yönden 'ulus-üstü’ sahici özel konumunu sürdürmektedir. Schuman Planı, Avrupa Kömür ve Çelik Birliği ile başlayan, Avrupa Birliği ile gelinen sürecin ulus devlet egemenliğini ulus-üstü bir egemenlik anlayışında yapılandırmaktadır. Ayrıca $A B$, siyasî, güvenlik, dış politika, savunma, adalet ve iç işleri ile ilgili alanlarda başlayan işbirliği sürecinden tam bütünleşmeye yeni bir Avrupa devletler sistemi oluşturmuştur. Bu bütünleşme sürecinde Avrupa egemen ulus devlet anlayışından -klasik uluslararası örgütlerden- farklı olarak yeni bir ulus-üstü egemenlik anlayışıyla Avrupa'da yeni bir siyasa oluşturması çalışmamızın ana kapsamı içinde olup, Avrupa ulus devletlerinin bu yeni yapılanmada hangi koşul ve şartlarda egemenliklerini Avrupa Birliği siyasasında farklı şekillerde kullandıkları incelenmektedir. Dolayısıyla AB hem kurumlarıyla üye ülkeler arasındaki rekabet ve işbirliğini çoklu düzeyde yönetişim sistemiyle başarılı yöneterek ulus-üstü güç, otorite ve yetkesini güçlendirecek (Esentürk, 2014, s1-20) hem de ulusal aidiyetli vatandaşların gözünde demokratik meşruiyeti gözeterek anarşik uluslararası sistemde kendisine sadık kıtasal ölçekte hiyerarşik bir ulus-üstü düzeni-siyasayı inşa etmek zor olacaktır.

AB'nin ulus-üstü yönetişime sadece Avrupalılar için yeni bir model olduğunu söyleyebiliriz. Fakat ABD benzeri "Birleşik Avrupa Devletleri" kurması üye ülkelerin çıkarları, kültürleri, ekonomik ve ulusal kurumları bir diğerinden oldukça farklıdır. AB'nin eski komünist, merkezi ve doğu Avrupa ülkelerine doğru genişlemesi onun siyasal bir kurum olarak klasik egemen devlet olma çabalarını güçleştirmiştir (Krasner, 2001, s20-29). 


\section{$84 \cdot$ YALOVA SOSYAL BILIMLER DERGISI}

Robert Schuman'nın “Avrupa askerî bir ittifak ve ekonomik bir topluluk hâline gelmeden önce kültürel bir topluluk olmalıdır (Waever ve Kelstrup, 1993, s65).” Şeklindeki ifadesi gibi, denebilir ki, Avrupa'nın ortak kültürel arka planı ve kimliği söz konusu sürece zemin hazırlamış ve ivme kazandırmış iken gelişen bütünleşme süreci de, Avrupa'nın Avrupalılaşma sürecine katkıda bulunmuştur (Morgan, 1996, s34-49). Bu yeni Avrupa yapılanma süreci egemen millî devlet eksenine inşa edilmiş, milliyetçilik yaklaşımı da yeni post-milliyetçilik şeklinde tanımlanma ihtiyacını doğurmuştur.

AB Komisyonu eski başkanı Romano Prodi, öğrencilerle internet ortamında yaptığı konuşmada; AB'nin Babil Kulesi'ne benzetilmesi karş1sında, kendi çabalarının ve bütün çalışmaların, gelecekte AB'nin bir trajediyle karşılaşmaması için yerel ve ulusal kimlik ve dillere oldukça saygılı bir siyasa öngörmelerinden kaynaklandığını söyler. Ayrıca, bugüne kadar olan süreçte AB'nin oldukça başarılı bir proje olduğunu, bunu AB'ye katılım için bekleyen ülkelerin somut olarak ispatladığını söyler (Prodi, 2001, s4).

Her ne kadar Avrupa anayasasina Fransa ve Hollanda'da referandum sonucunda 'hayır' çıksa da AB ülkeleri, bazı sembol söylemlerden vazgeçerek $A B$ bütünleşmesine devam kararı (Lisbon Antlaşması) almışlardır. Avrupa Birliği ülkeleri önceki devlet yapılanmalarından farklı olarak yeni bir ulus-üstü siyasa otorite formunda bir araya gelmişlerdir (Rabkin, 2000, s2). Önceki kurucu birçok antlaşmanın (Roma, Maastricht, Amsterdam,) genelde farklı ekonomik, sosyal, kültürel ve karmaşık teknik içerikli olması AB'nin tüm bu antlaşmaları kapsayan daha somut anayasal çerçevede siyasî bir antlaşma yapması gerekliliğini doğurmuş; fakat başarısız olunmuştur. Ancak Lisbon antlaşması ile üye ülkelerin mutlak egemenliklerine ilişkin bazı tereddütler (tek bir devleti çağrıştıran bayrak, millî marş, anayasa gibi semboller) giderilerek; AB'de derinleşme, genişleme ve siyasî birlik yeniden entegrasyon sürecine koyulmuştur (Akdoğan, 2010, s64).

AB'nin geldiği son süreçle ilgili birçok farklı yaklaşım vardır. Jan Zielonka, Avrupa entegrasyon sürecinin bir devlet inşa süreciyle doğrudan bir paralellik gösterdiğini söyler. Bu sürecin ilk olarak Vestfalya ben-

YIL: 5 SAYI: 10 
zeri bir süper devlet hedeflediğini belirtir. Avrupa Birliği ile ortaya çıkan siyasayı yeni Orta Çağ imparatorluğuna benzetir. Genişleme sürecinden başka birçok faktör, Vestfalya benzeri bir senaryo devletin ortaya çıkışını engellemiştir. Fransız ve Hollandalı seçmenler AB'nin anayasal antlaşmasına 'hayır' demekle aslında “Avrupa Devleti'ne hayır, Avrupa İmparatorluğuna evet” demiş oluyorlardı. Gerçekte birçokları Avrupa Anayasası'nı Avrupa Devleti inşa sürecinde dönüm noktası olarak görüyorlard1. Avrupa süper devleti gerçekleşmediğine göre ufukta Avrupa Birliği için bir tür yeni Orta Çağ imparatorluk sistemi öngörülmektedir. Bu sistemin temel özellikleri; kendine has çok merkezli hükümet sisteminin, çoklu ve çakışan yargısal sistemin, çarpıcı farklı kültürel ve ekonomik çeşitliliğin, belirsiz sınırlar ve bölünmüş egemenlik yapısının olmasıdır. AB, Soğuk Savaş sonrası iki-üç Avrupa'yı birleştiren ekonomik sistemi ve demokratik yönetişimiyle modernleşmenin, karşılıklı bağımlılığın ve küreselleşmenin artan tehditlerine karşı bir alternatif oluşturmaktadır. Aynı zamanda hem Avrupa'da hem de Avrupa dışında barışçıl bir sistem geliştirmiştir (Zielonka, 2006, s5).

Romano Prodi şu anki AB'nin siyasî durumunu birleşmiş bir Avrupa devleti olarak görmediğini, AB'nin bir devlet olmadığını; ancak uluslararası örgütlerden daha fazla, devletten ise daha az bir yapı olduğunu ve bu süreçte egemenliğin ortak bir havuz olarak birlikte kullanıldığını vurgular. Devletlerin egemenliğini kaybetmediğini, egemenlik konusunda da devletlerin karar verdiğini üye ülkelerin bu süreçte kendi dolaylı rızaları ile AB uygulamalarını kabul ettiklerini belirtir (Prodi, 2001, s8-42).

Bunun yanında, devlet dışı örgütler ve sivil toplum örgütleri AB'nin yapısı hakkında siyasal partilere ve hükümetlere ihtiyaç duyulmadan yönetişimi sağlayan, devlet olmayan bir sistem olarak görürler. Bu sebeple $\mathrm{AB}$, dünyanın en etkili ve büyük bir hükümet-dışı örgütüdür. İkinci olarak ise devlet-dışı yaklaşım, kendi etrafında daireler çizen ve üye devletlerinin egemenliğini kaybetmediği, sürekli ilerleyen bir AB inşası öngörür (Plattner, 2005, s5).

Avrupa Birliği’nin siyasi, ekonomik, sosyal ve kültürel alanlarda yapmış olduğu bölgesel düzeyde örgütlenmesiyle ilgili birçok isimlendirmeler 
ve sıfatlar uydurulmuştur. AB; çok milletli ya da çok uluslu, çok kültürlü ve çok dilli devlet, ulus-ötesi ya da ulus-üstü devlet, küresel ya da bölgesel devlet, federal devlet (federation), federal devletler birliği (Confederation), üniter ya da tam devlet olmayan, kendine has (sui generis) bir düzendir. Krasner ise AB'yi nötr mutasyona uğramış bir yapı olarak ifade eder.

AB'nin bu değişken siyasi yapısını ve Anayasal fizyonomisi için uyum sistemi (concordance), ortakl1k (condominio), konfederal birliktelik, ittifak (confederance), konsorsiyum (konsortio), uluslararası devlet, düzenlenmiş toplum, piyasa siyasası, karışık ortak mülk, çok düzeyli siyasa, neo-cumhuriyetçi sistem, yarım devlet, proto-federal, bölgesel rejim, düzenleyici devlet, yönetim sistemi gibi tanımlamalar yapılmaktadır. Aslında, bu kurgulanmış isimlendirmeler egemenlik çelişkisinin entegrasyon, otonomi ve karşılıklı bağımlılık, düzen ve parçalanma, birlik ve farklılaşma, idare etmek ile kontrol arasındaki ikircikli durumdan çıkmaktadır (İnanç ve Özler, 2007, s114-116). Bu kavramlara devletler ligi, ittifaklar, müttefikler, jeopolitik ve jeo-stratejik gibi belirli durumlardaki ulus devlet ilişkilerini düzenleyen kavramları da ekleyerek çoğaltabiliriz.

Avrupa Birliği'nin egemenlik bağlamında sahip olduğu unsurları toprak, tanınma, kontrol, millî otorite, extra-millî otorite, ve ulus-üstü otorite olarak sayabiliriz. AB kurumlarını; Avrupa Komisyonu, Avrupa Merkez Bankası, Avrupa Adalet Divanı, Avrupa Parlamentosu ve Avrupa İnsan Hakları Mahkemesi şeklinde ulus-üstü otorite yapıları olarak nitelendirebiliriz. Avrupa'yı bir kılan Adalet Divanı'nın geliştirdiği dört önemli doktrin vardır. Bazı analizcilere göre, bu kurumların federal devletin hukukî yapısından bir farkı yoktur. Direkt etki, üstünlük, nihai güç ve AB'nin insan haklarını ihlal eden kararlarının gözden geçirilmesi hakkı gibi unsurlar bu görüşü doğrulamaktadır (Krasner, 2001, s244-245).

Avrupa Birliği Komisyonu'nun AB'nin yasama sürecini başlatan yasa tasarısı hazırlayabilme gücü, bu kurumun ulus-üstü özelliğe sahip olması bakımından çok önemlidir. Ayrıca Avrupa Konseyi bazı konularda nitelikli çoğunlukla karar verir ki; bu kurum 1949'da Avrupa'da insan hakları ihlallerini önlemek amacıyla hükümetler-arası bir yapı olarak kurgulanmıştır. Fakat kendisine bağlı Avrupa İnsan Hakları Mahkemesi'nin etkin ka-

YIL: 5 SAYI: 10 
rarlarıyla bir ulus-üstü kurum haline gelmiştir. Bu bağlamda ulusal mahkemeler, kararlarında, bu mahkemenin içtihatlarıyla uyumlu karar almaya çalışırlar. AB de ayrıca 2000 sonrası süreçte bu Konvansiyonu imzalayarak insan haklarını kurumsal olarak önceleyen bir düzen olduğu mesajını dünyaya vermek istemiştir.

Avrupa'nın geleceği hiç bu kadar net olmamıştı. Genişleme, Euro, ortak savunma ve güvenlik kimliği ve oldukça iddialı ortak ekonomik ve sosyal birlik hedefleri Lisbon'da belirlendi. Fakat Avrupa merkezli millî, siyasî ilgisizlik, yaşlanan toplum, işsizlik, emek ve refaha tehditler, s1nır-aşan iklim değişimleri, uluslararası suç, uyuşturucu, göç gibi sorunlar AB'nin geleceğini tehdit eden önemli sorunlardır. AB, üye vatandaşlarının ve üye devletlerinin artı değerini arttırabilmek için ar-ge yatırımlarında ve eğitimde ABD ve Japonya'yı geçmek zorundadır (Leonard ve Arbuthnott, 2001, s5).

AB'nin oluşumu modern çağda, devletlerin kendi ulusal iradeleriyle, ilk kez temel egemenlik haklarından kısmen vazgeçtikleri ya da yeniden yapılandırdıkları bir süreçtir. Orta Çağ'dan bu yana şekillenen modern egemen ulus devletlerin tekelinde olan dört temel egemenlik hakkı para basma tekeli, vergi koyma tekeli, sınırlardan kimin içeride kimin dişarıda kalacağının tayini ve silahlı gücün kontrolüdür. $\mathrm{AB}$ birlik süreci, mali federasyon ve vergi koyma dışında sistemsel olarak ulus devletlerin yetkisinde olan her konuda ulus-üstü otoritelere transfer edilen bir süreçtir. Para basma yetkisinin (seigneural ve regalien hakkı) ulus-üstü ve otonom bir kuruma devredilmesi, esasen o devletin para politikası alanındaki yürütme gücünü elinden almış olur. Ayrıca üye ülkeler AB'nin Merkez Bankası'nın para politikalarına, dolayısıyla kendi iktisat politikalarını da uyarlamak zorundadırlar. Ayrıca AB Amsterdam Anlaşmasıyla üye ülkeler; AB'nin üç ayağından biri olan Adalet ve İçişleri (Bache ve George, 2006, s372374) başlığında vize, mülteci ve göçmen konularının (polis-güvenlik) bir bölümünü "hükümetler-arası işbirliği”" konumundan, federal topluluk politikası seviyesine getirmeyi amaçlar. 1 Mayıs 2004 itibariyle Adalet ve Polis İşbirliği (EUROPOL) alanına giren göç ve iltica politikaları da dolayısıyla topluluk politikasının bir unsuru olmuştur. Bu gelişmeler çerçevesinde, federal politika olan ortak vize politikasılyla (Schengen), Bir- 
liğin diş sınırlarının siyasî kontrolünün 2004'te federal makamlara devri Ortak Pazar'la "kişilere serbest dolaşımı” ve iç sınırlarını kaldırmış olan AB ülkeleri ilgili egemenlik haklarını devretme süreçlerini tamamlamış olacaklardır (Aktar, 2002, s105-109). Europol uyuşturucu, terörizm, insan kaçaklığı, dolandırıcılık, vb. suçlarla mücadelede adli ve güvenlik konularında çalışan ulus-üstü bir polis merkezi olacaktır.

Ayrıca, Avusturya, Belçika, Finlandiya, İrlanda, Almanya, İspanya, Fransa, Lüksemburg, Hollanda, Portekiz ve İtalya -Avrupa Para Birliğigibi AB ülkeleri 1 Ocak 1999'dan itibaren resmen hukukî olarak Euro'yu ulusal para birimi olarak kullanmaya başlamışlardır (Temporten, 1998, s1). Newsweek dergisi bu durumu "Eski Dünyaya Yeni Para" başlığı ile duyurur. Avrupa Para Birliği’nin AB'nin geleceğini siyasî, ekonomik ve kurumsal yönden Avrupa kitasında ve dünyada çok olumlu anlamda etkileyeceğini söyler (Hirsh, 1999, s4-104). AB Ortak Merkez Bankası'nı 1999 yılında on bir üye ülke ile kurmayı başarmıştır (Norland, 1999, s1415). 2002'den itibaren Euro dünya piyasalarında dolaşımda bulunan bir paradır. Daha sonra Maastricht Antlaşmasıyla kurulan Avrupa Para Birliği'nin kriterini karşılayan Yunanistan da Euro ligine katılmıştır. Bu açıdan para üzerindeki ulusal egemenliğin paylaşılması -transfer edilmesi- ortak kullanılması başarılı bir şekilde yürütülmektedir. Almanya gibi bazı ülkeleri uyaran, Avrupa komisyonu ceza uyarısında bulunmuştur. Para birliği ülkenin bağımsızlığının sembolü olan para üzerindeki kontrolünü azaltır. Para birliği siyasî birlik yolunda atılmış siyasî ve malî federalizmi teşvik eden önemli bir unsurdur. Tarihte para birliği sonrasında Belçika ve Luxemburg gibi siyasi birlikler kurulmuştur. Ayrıca bu birlik; ulusal egemenliğin zayıflaması, egemen ulus devletin maliye, piyasa, ticaret, bütçe, enflasyon, vergi, senyoraj gibi birçok alanda denetim ve düzenleme, (Lex Moneteux) uluslararası ekonomideki kontrol gücünü tek başına kullanmasını elinden alır (Currie, 1997). Finansal ve borç krizinde AB çok zorlansa da Euro-bölgesinde Bankalar Birliğini kurarak ayrıca kriz yaşayan ülkelere borç vermede hem parasal hem de malî denetimde kısmen malî federal derinliği güçlendirmiştir, diyebiliriz. Fakat, hâlâ üye ülkeler AB karar alma süreçlerinde demokratik meşruiyetin temeli olarak ulusal devlet egemenlik yaklaşımını sürdürmektedirler. 
AB Merkez Bankası'nın oluşumunda ve yapılanmasında, Alman Bundesbank etkili olmuştur. Çünkü bu banka Almanya'da enflasyonla mücadelede ve para politikasında büyük bir başarı göstermiştir. Buna sebep olarak da kurumun anayasal olarak özerk yapılanmasının büyük rolü olmuştur. Avrupa Merkez Bankası'nın merkezinin Frankfurt olması bu şehrin yeni bir finans merkezi olması açısından da önemlidir. Fakat konumuz açısından Euro'ya katılan on iki ülke para konusundaki millî egemenliklerini Avrupa Merkez Bankasıyla birlikte paylaşarak, havuzlayarak, ikame ederek transfer etmiş oldular. Burada İngiltere, Danimarka, İsveç; Maastrict Euro kriterlerini (Bendit ve Duhamel, s182-185) karş1lamalarına rağmen bunu ulus-üstü siyasî birlik olarak gördükleri için; ayrıca İngiltere Almanya'nın en güçlü ekonomi olarak AB' de para politikasını belirleme korkusuna rağmen Euro Ligine katılmayarak para konusunda egemenliklerini transfer etmek istemediler (Roskin, 2013, s67). Ancak İngiltere (Miles, 1998, s93-106) ve Danimarka anlaşmayla şimdilik Euro bölgesi dişında kaldılar (Gustafsson, 1998, s107-120). 2006'da Slovenya da Euro bölgesine katıldı ve 2008'in ortasinda Malta ve Kıbrıs da Euroland bölgesine katılınca üye sayısını on beşe yükselten Euro'ya şimdi ise AB'nin on yedi ülkesi üyedir. Daniel C. Bendit, "Bağımsız bir Avrupa merkez bankasınca yönetilen tek paranın yaratılması, federalizmin fazladan bir aşaması olmaktadır." şeklinde yorumlar (Bendit ve Duhamel, s125-126).

Fransa ve Hollanda'da Avrupa Birliği için oluşturulan anayasaya ret oyu çıkması büyük bir hayal kırıklığı meydana getirmiştir. Birlikle ilgili meşruiyet ve demokrasi tartışmaları gündeme getirilmiştir. Gerçi konuya tersten baktığımızda AB'de anayasal yapılanmaya gidilmesine ve Birliğin genişleyerek yirmi yedi üyeli olmasına halkın demokratik ve meşru bir tepkisi olarak bakabiliriz.

Bu bağlamda François Mitterand'a Avrupa Birliği anlaşmasını Fransız parlamentosunun $\% 90$ onayladığını, dolayısıyla niçin referanduma gidildiği sorusuna şöyle cevap verir: Avrupa yapılanmasının meşru bir demokratik temele oturtulmasından dolayı bizi niçin kınıyorsunuz. Halkın gerçek rızası olmaksızın yapılan bir onaylamanın riski daha büyük olmaz mı?" Ayrıca Kömür Çelik Birliğinden, Avrupa Birliği’ne kadar birçok yeni oluşum içine girildiğini belirterek, bu 40 yıllık suskunluğun bedelini bugün 
ödüyoruz diyerek AB elitlerinin teknokratik kurumsallaşma icraatlarını eleştirir (Verdin, 1999, s491-500). Bu çerçevede üye devletlerin kabulü, Amsterdam, Köln, Nice ve AB anayasası gibi birçok devasa antlaşma, Avrupa ulus devletlerinin kaderini belirleyecek birden fazla sosyal sözleşme için halkın rızasının aranması demokratik meşruiyet açısından doğaldır diye düşünüyoruz. Lizbon anlaşmasında AT'nin yerine AB'nin ve sütunların kaldırılması AB'nin entegrasyonu derinleştirme konusunda başarılı olduğunu, ekonomik krizle birlikte AB'nin 2020'ye kadar genişlemekten ziyade derinleşmeye odaklanacağı anlaşılmaktadır.

$\mathrm{Bu}$ bağlamda dünyada bölgesel ekonomik işbirliği çabaları artmaktadır. Örneğin Kuzey Amerika'da kurulan Nafta, bölgedeki ekonomik işbirliğini artırmayı amaçlamıştır. Fakat bu tür anlaşmalar dünyanın en güçlü ülkesinde bile egemenlikle ilgili tartışmaları gündeme getirmiştir (Gaffney, 2007, s1-2). Aynı şekilde AB ve NATO’nun genişlemesi Rusya ve Çin'i gerek Şangay İşbirliği Örgütü gerekse Avrasya Ekonomik Birliği gibi ekonomik, gümrük, mali, finansal ve yeni üyelik konusunda genişleme, derinleşme ve rekabetçi bir pozisyona yönlendirmektedir. Bu durum ise AB ile rekabet halinde olan Avrasya örgütlerinin Kopenhag gibi somutlaşmış Vestfalya liberal, demokratik, hukuk devletinin temel ekonomik ve siyasî kriterlerine alternatif bir kimlik ve kurumsal bir değere sahip olmaması, bölgedeki büyük güçlerin (BM Konsey’inde veto gücüne sahip ya da değil) askerî ve ekonomik olarak zayıf egemen ulus devletlerin sözde Ekonomik Entegrasyon ve Birlik adına iç işlerine müdahale edebilmektedir.

\section{Sonuç}

Kıta Avrupa'sında ortaya çıkan ulus devlet sistemi, yüzyıllarca büyük güçlerin yıkıcı rekabet ve savaşlarının sonunda, yarım asırdır devletlerin yönetişimini başaran yeni bir yapıyı, klasik realist bağlamda anarşik devlet doğasını aşan bir devletler düzenini, Avrupa Entegrasyonu bağlamında uluslararası sistemde oluşturmuştur (Stein, 2010, s283).

Bağımsız egemen ulus devlet sistemi, bir yandan uluslararası entegrasyonla diğer yandan ise etnik ve mikro milliyetçiliklerin tesiri altında 
küresel kapitalist Pazar ekonomisine Batı'da AB, GATT, NAFTA (Dikkaya ve Özyakışır, 2008, s88-89) vb. yeni kurumlarla ulus devlet egemenliğini yeniden yapılandırarak sistemik bir düzenle uyum sağlamaya çalışmaktadır.

AB genel anlamda Batı Avrupa'da altı üye devlet arasında belirli alanlarda ekonomik entegrasyonu hedefleyen bir hükümetler-arası kuruluş gibi görünse de temelde başından beri AKÇT gibi ulus-üstü karakterini ortaya koyan kurumsal organizasyon ve antlaşmalarla ortaya çıkmıştır. Fakat AB'ye üye ülkeler Avrupa'ya barış, dayanışma, istikrar ve refah getirmek için entegrasyon sürecini desteklemelerine rağmen ulusal egemenlik gibi konularda AB'nin ulus-üstü kurumlarına karşı 'hükümetler-arası kurum' yaklaşımını göstermişlerdir.

Avrupa Entegrasyon tarihine baktığımızda Avrupa Parlamentosunun gelişimi-güçlenmesi; Avrupa vatandaşlığı, Avrupa İnsan Hakları Sözleşmesi, Avrupa Anayasası vb. çok geç gerçekleşmiş ya da kısmen başarısız olmuştur. Aynı şekilde, AB sivil toplum ve hükümet dışı kuruluşlarla da geç bir zamanda resmi ilişkiler geliştirmiştir. Maastrict Anlaşması'yla sosyal politika ve sivil diyalog alanında, ekonomik ve sosyal komitenin işçi, işveren ve sivil toplumun farklı temsilcilerinin katılmasını istediğinden, AB Komisyonu 2000 sonrası her yıl Hükümet-dışı Örgütlerin kalkınma ve insanî gelişim projelerine 1 Milyar Euro desteği vermektedir (Başlar, 2005, s167-169). Ayrıca, AB Anayasa yapım sürecine hem resmi üye devlet ve birlik temsilcilerinin hem de sivil toplum temsilcilerinin katılmasi (Arsava, 2000, s693), nihayetinde Hollanda ve Fransız halkı tarafindan reddedilmesi entegrasyon sürecinin demokratik halk egemenliğinin entegrasyon sürecinde etkili olmaya devam ettiğini gösterir. Bununla birlikte 'yerindenlik' (subsidiarity) ilkesi AB, üye ülkeler, bölgeler ve yerel yönetimler ölçeğinde ulusal-iç ve dış-ulus-üstü egemenlik yetkisinin ölçülü ve demokratik meşruiyet içerisinde kalarak egemenliğin yapılandırılması, sınırlandirılması, kısıtlanması, transfer edilmesi, ikame edilmesi, havuzlanması, paylaşılması, ortak olunması ve çoklu boyutta $A B$ entegrasyon ve yönetişimi ucu açık şekilde gerçekleşmektedir. 


\section{$92 \cdot$ YALOVA SOSYAL BILIMLER DERGISI}

Avrupa Topluluklarının temel kurucu metinleri, egemen bağımsız ulus devletler tarafından uluslararası antlaşmalar niteliğinde imzalanmış, ancak yapılan bu antlaşmalar uluslararası hukuktan yararlanılarak yapılsa da temel dört kurumsal yap1; Adalet Divanı, Konsey, Komisyon, Parlamento oluşturulmuştur (Tezcan, 2005, s1). Bu yönüyle de AB Hukuku klasik uluslararası hukuktan bağlayıcılık, uygulama ve kapsam bakımından yeni bir iç hukuk düzeni oluşturması yönünden ayrılır. Dolayısıyla klasik egemen devletlerin iradesiyle kurulan $\mathrm{AB}$ üye ülkelerin yargısal, yasama ve yürütme alanındaki klasik ulus devlet egemenlik anlayışını Krasner'in yaklaşımıyla entegrasyon mantığı içerisinde ulus-üstü egemenliğini 'organize' inşa ya da Vestfalya-sonrası bir düzen şeklinde yapılandırmaktadır. $\mathrm{AB}$ kendisine has örnek kurumsal yapılanması ile ulus-üstü bir siyasal sistem olarak devlet, düzen, sistem, hukuk oluşturmasına rağmen üye devletlerin ulusal egemenlik, hukuk ve devlet yapılanmalarının yerini alamamıştır; ama onlarla birlikte varlığını sürdürmektedir.

AB ulus-üstü yönetişimiyle iç ve diş alanı olan bir siyasal sistem olarak istikrarlı ve somut kurumlarıyla sürekli bir şekilde kendi sosyal gruplarıyla etkileşim halinde ortak kararlar alabilmektedir. Vatandaşlar ve toplumsal dinamikler hem $\mathrm{AB}$ düzeyinde dolaylı ve doğrudan çıkar gruplarıyla ya da siyasi partiler aracılığıyla taleplerini karşılamaktadırlar. Esas olarak AB düzeyinde ulus-üstü yasama süreci ekonomik kaynakların yeniden dağıtımı açısından vatandaşların sosyal ve siyasi değerlerini etkilemektedir. Bununla birlikte AB temel klasik devlet özelliklerinden tek hükümet, tek dış politika ve hazır bir orduya sahip değildir. Elbette AB'nin kararları hala üye ülkelerin yasama, idari ve cebri yürütmesine bağlıdır. $\mathrm{Bu}$ durum AB'yi siyasi sistem olarak bir Avrupa devleti olmasını elbette gerektirmez (Rasmussen, 2009, s34).

Fakat 11 Eylül sonrası yaşanan süreçte liberalleşme, küreselleşme ve uluslararası örgütlenmeler ve Avrupa Entegrasyonunun derinleşmiş boyutuna rağmen gelinen evrede milliyetçilik hâlâ güçlü bir siyasî ideoloji olarak, klasik realist çerçevede, devleti kollaması açısından ulus devletlerin yakın gelecekte de varlıklarını sürdürecekleri görünmektedir (Mersheimer, 2013, s.91). Ancak küreselleşmeyle birlikte, ekonomik ve malî istikrarsızlıklar, uluslararası göçler, terörizm, radikalizm, yabancı düşmanlığg, ayrı-

YIL: 5 SAYI: 10 
lıkçı mikro milliyetçilikler ve AB'nin çevresindeki jeo-politik kırılmaların tehdit ve riskleri, AB üye devletlerini entegrasyon sürecini derinleştirmekten alıkoymayacaktır. Dolayısıyla $\mathrm{AB}$ dış politika, güvenlik, ekonomi ve diplomaside küresel bir siyasi egemen aktör olarak kapasitesini artırmak istemektedir (Ginsberg ve Smith, 2007, s.282). AB ABD'den farklı olarak diğer ülkelerle olan ilişkilerinde üyelikten işbirliğine yapısal ve sistemik olarak hukuki, jeopolitik, ekonomik ve sosyal dönüşümünü gerçekleştirmektedir (Dağc1 ve Dağc1, 2007, s.39-46).

\section{Kaynakça}

Akdoğan, Muzaffer., “Avrupa Birliği ve Birlik Üyesi Ülkeler Arasında Egemenlik İlişkisi”, Uluslararası Hukuk ve Politika, Cilt.6, Sayı.24, 2010, s.64. (http://usak.org.tr/images_upload/files/uhp\%2024\%20makale3.pdf)

Aktan, Okan H., Para Birlikleri Kuramı ve Avrupa Para Sistemi, (Ankara: Hacettepe Üniversitesi İ̈BF Yayınları, No.4, 1983).

Aktar, Cengiz., "Ulusal Egemenliğin Devri ve Ulus-üstü Zeminde Paylaşımı", Radikal Gazetesi, 26 Ocak, 2001.

Aktar, Cengiz., Yol Ayrımında Türkiye, (İstanbul: İletişim Yayınları, 2002).

Alakel, Murat., Türkiye Avrupa Birliği İlişkilerinde Egemenlik Sorunu, Uluslararası İliş̧kiler, Marmara Üniversitesi, 2008, Yayınlanmamış Doktora Tezi.

Altunbaş Akgül, Deniz., "Türkiye Avrupa Birliği İlişkilerinde Egemenlik Sorunu", 2004.

Amin, Ash. - Dietrich, Michael., Towards a New Europe: Structural Change in the European Economy, (Brookfield: Edward Elgar Publishing Limited, 1991).

Arsava, Ayşe Füsun., “Avrupa Anayasası Yolunda Avrupa ve Ulusal Anayasa Hukuklarının Karşılıklı Etkileşimi”, Yeni Türkiye: Avrupa Birliği Özel Sayısl, S.35, Y.6, Eylül-Ekim 2000.

Aziz, Miriam., "Sovereignty Lost, Sovereignty Regained? European Integration Project and the Bundesverfassungsgericht", European University Institute Working Papers, 2001/31. 


\section{$94 \cdot$ YALOVA SOSYAL BILIMLER DERGISI}

Bache, Ian.- George, Stephen., Politics in the European Union, (Oxford University Press, 2006).

Barnett, Michael N.- Finnemore, Martha., "The Power of International Organizations", İçinde Richard Little ve Michael Smith(der.), Perspective on World Politics, (Routledge, 2006).

Başlar, Kemal., Uluslararası Hukukta Hükümetdışı Kuruluşlar: Vestfalya-Sonrası Süreçte Küresel Sivil Toplum, USAK, (Nobel Yayın, Ankara, 2005).

Bennet, A. Leroy.- Oliver, James K., International Organizations: Principles and Issues, ( New Jersey: Pearson Education, 2002).

Bozkurt, Enver.- Özcan, Mehmet.- Köktaş, Arif., Avrupa Birliği Hukuku, (Ankara: Nobel Yayın Dağıtım, Nisan 2001).

Bozkurt, Veysel., Avrupa Birliği ve Türkiye, (İstanbul: Alfa Yayınları, 1997).

Caporaso, James A., "Changes in the Westphalian Order: Territory, Public Authority, and Sovereignty", Blackwell Publishers, 2000.

Caporaso, James A., "The European Union and Forms of State: Westphalian, Regulatory or Post-Modern?", Journal Of Common Market Studies, Vol.34, No.1, Mart 1996.

Chon-Bendit, Daniel. - Duhamel, Oliver., Euro İçin Küçük Sözlük, Turhan Ilgaz (çev.), (İstanbul: Yapı Kredi Yayınları, Nisan 1999).

Currie, David., "The Pros and Cons of EMU”, Economic Intelligence Unit, February 1997.

Çakır, Emre Armağan., Avrupa Bütünleşmesinin Siyasal Kuramları, (İstanbul: Beta Yayınları, Eylül 2001).

Dağc1, Kenan.- Dağc1, Gül Tuba., Rethinking Turkey EU Relations, (Münster: MV Wissenschaft, 2007).

Dedeoğlu, Beril., Adım Adım Avrupa Birliği, (İstanbul: Çınar Yayınları, 1996).

Deporte, A.W., Europe Between the Superpowers: The Enduring Balance, (New Haven ve London: Yale University Press, 1986).

Dikkaya, Mehmet.- Özyakışır, Deniz., Küreselleşmenin Ekonomi-Politiği, (Ankara: Gazi Kitabevi, 2008), ss.88-89.

Dinan, Desmond., Ever Closer Union: An Intrdoduction to the European Community, (Colorado: Lynne Reinner Publishers, 1994).

YIL: 5 SAYI: 10 
AVRUPA BÜTÜNLEŞMESI SÜRECINDE: HUKUK, DEVLET VE EGEMENLIK,,,' 95

Dulles, John Foster., War Or Peace, (New York: MacMillian Co., 1957).

Esentürk, N. Nevra., "EU Governance: Cooperation Between Competition", Alternatives:Turkish Journal of International Relations, Say1.13, No:1-2, (Spring-Summer, 2014), ( https://www.alternativesjournal.net/?menu=pages\&p=issue_details\&id=24 ) 11.12.2014

European Commission, IEA, "Enlargement: Europe, Past, Present and Future", Ekim 2001.

Faculty of Political Sciences and International Affairs University of Matej Bel, Banská Bystrica, Models of European and World Integration, International Conference: September 12-14 2001.

Faculty of Political Sciences and International Affairs University of Matej Bel, Banská Bystrica, World, Europe and National State, (Bankska Bystrica: 2004).

Gaffney, Frank J., "Eroding of Sovereignty”, The Washington Times, 21 Ağustos 2007. (http://washingtontimes.com/article/20070821/COMMENTARY03/108210002/1012)

Giddens, Anthony., Diamond, Patrick., ve Liddle, Roger., (drl.), Global Europe Social Europe, ( USA: Polity Pres, 2006).

Giffiths, Martin ve O'callaghan,Terry., International Relations: The Key Concepts, Routledge, 2004.

Ginsberg, Roy H.- ve Smith, Michael H., “ Understanding the European Union As a Global Actor: Theory, Practice and Impact" İçinde Der. Sophie Meunier ve Kathleen R. Mcnamara, The State of the European Union, (Oxford University, 2007).

Giordano, Francesco.- Persaud, Sharda., The Political Economy of Monetary Union: Towards the Euro, (London-New York: Routledge, 1998).

Gözler, Kemal., "İnsan Hakları Normlarının Anayaüstülüğü Sorunu”, İçinde Türkiye'de Insan Haklarl, (Ankara: TODAİE Yayını, 2000). ( www.anayasa.gen.tr/insan.htm; 1.5.2004).

Gustafsson, Ake., "The Nordic Countries and the Euro", İçinde, Paul Temporten, The Euro, (New York: John Wiley\&Sons, 1998).

Gündüz, Aslan., "Eroding Concept of National Sovereignty: The Turkish Example", Marmara Üniversitesi Avrupa Topluluğu Araştırma Dergisi, Cilt.1, Say1.1-2, 1991. 
$96 \cdot$ YALOVA SOSYAL BILIMLER DERGISI

Habermas, Jürgen., Küreselleşme Baskısı Ve Millı̂ Devletlerin Akibeti, Medeni Beyaztaş (çev.), (İstanbul: Bakış Yayınları, Mart 2002).

Hasgüler, Mehmet.- Uludağ, Mehmet B., Devletlerarası ve Hükümetler Dışı Uluslararası Örgütler, (Alfa Yayınları, 2010).

Hirsh, Michael., "New Europe, New World”, Newsweek, Özel Sayl: EuroLand, November 1998- January 1999.

Hix, Simon., The Political System of the European Union, (New York: Palgrave Macmillian, 2005).

İnanç, Hüsamettin.- Özler, Hayrettin., "Democratic Deficit in EU: Is there an Institutional solution to Over-Institutionalization?", Alternatives: Turkish Journal of International Relations, Cilt.6, Say1.1\&2, Bahar-Yaz 2007.

İyibozkurt, Erol., “Türkiye AB İlişkileri Gümrük Birliğinden Öteye Gidemez”, Yeni Türkiye: Avrupa Birliği Özel Sayısı, Y11.6, Sayı.36, Kasım-Aralık 2000.

Karluk, Rıdvan., Avrupa Birliği ve Türkiye, (İstanbul: İstanbul Menkul Kıymetler Borsası Yayınları, Nisan 1996).

Kennedy, Tom., Learning European Law: A Priemer and Vade-mecum, (London: Sweet\&Maxwell, 1998).

Keyder, Çağlar., Memalik-i Osmaniye'den Avrupa Birliği'ne, (İstanbul: İletişim Yayınları, 2003).

Khan, Ali., "The Extinction of Nation-States", American University Law Review, Vol.7, 1992.

Koray, Meryem., Avrupa Toplum Modeli, (Ankara: İmge Kitabevi, Haziran 2005).

Krasner, Stephen D., "Sovereignty”, Foreign Policy, Vol.122, 2001.

Krasner, Stephen., “Abiding Sovereignty”, International Political Science Review, Vol.22, No:3, 2001.

Krasner, David., "Rethinking Sovereign State Model", Review of International Studies, Vol. 27, 2001.

Lasok, Dominic.- Lasok, K.P.E., Law \& Institution of the European Union, (London: Butterworths, 1994).

YIL: 5 SAYI: 10 
AVRUPA BÜTÜNLEŞMESI SÜRECINDE: HUKUK, DEVLET VE EGEMENLIK,,,' 97

Leonard, Mark.- Arbuthnott, Tom., "Rethinking Europe", 6-8 September Praque Castle Conference, 2001. (http://fpc.org.uk/fsblob/71.pdf), (03.08.2007).

Linberg, Leon N., The Political Dynamics of European Economic Integration, (USA: Stanford University Press, 1963).

Madde 2, F1kra 1, Charter of the United Nations and the Statute of the International Court of Justice, (Birleşmiş Milletler Kamu Bilgilendirme Ofisi, 1994).

Martinez, Magdalena M., National Sovereignty and International Organizations, (Hague: Kluwer Law International, 1996).

Mcgoldrick, Dominic., International Relations Law of the European Union, (London, New York,: Longman, 1997).

Measrheimer, John J., "The False Promise of International Institutions", International Security, Vol. 19, No.3, Winter 1994/95.

Miles, David., "The Options for the UK", İçinde, Paul Temporten, The Euro, (New York: John Wiley\&Sons, 1998).

Morgan, Philip., “A A Vague and Puzzling Idealism' Plans for European Unity in the Era of the Modern State", İçinde Michael Wintle (der.), Culture and Identity in Europe, (England, Aldershot: Avebury, 1996).

Murphy, Alexander B., "International Law and the Sovereign State System: Challenges to the Status Quo", İçinde George J.Demko (der.), Reordering the World: Geopolitical Perspectives on the Twenty-First Century, (Boulder, CO: Westview Press, 1999).

Nelsen, Brent F. - Stub, Alexander C-G., The European Union: Readings on the Theory and Practice of European Integration, (Boulder, CO: Lynne Reinner Publishers, 1998).

Nelsen, Brent F. - Stub, Alexander C-G., The European Union: Readings on the Theory and Practice of European Integration, (Boulder, CO: Lynne Reinner Publishers, 1994).

Norland, Rod., “Look Who's Invited to Dinner”, Newsweek, Özel Sayl: EuroLand, November 1998- January 1999.

Oder, Bertil Emrah, "Topluluk Hukukunun Temel Doktrinleri ve Uygulanması", İçinde Gülören Tekinalp ve Ünal Tekinalp, Avrupa Birliği Hukuku, ( İstanbul: Beta Basım Yayım, 2000). 
- yALOVA SOSYAL BiLIMLER DERGiSi

Öz, Mehmet., “Avrupa Birliği, Anayasasının AB Kurumlarına Etkisi”, Uluslararası Stratejik Araştırmalar Kurumu, Uluslararası Hukuk ve Politika, Cilt:1, No:1, 2005.

Pazarc1, Hüseyin., Uluslararası Hukuk, (Ankara: Turhan Kitabevi, 2007).

Pease, Kelly-Kate S., International Organizations, (Pearson, 2012).

Pease, Kelly-Kate S., International Organizations: Perspectives and Governance, (N.J.: Prentice Hall, 2003).

Pentland, Charles., International Theory and European Integration, (New York: The Free Press, 1973).

Peterson, John., "The European Union: Pooled Sovereignty, Divided Accountability", Political Studies, Vol. XLV, 1997.

Plattner, Marc P., "Sovereignty and Democracy", Journal of Democracy, s.5. (http://www.policyreview.org/dec03/plattner.html), 30.07.2005.

Rabkin, Jeremi., "Is National Sovereignty Out of Date", Institute of Public Affairs, 2000.

Rasmussen, Morten., "Supranational Governance in the Making: Towards a European Political System", İçinde (der.) Wolfram Kaiser, Brigitte Leuchte ve Morten Rasmussen, The History of the European Union: Origins of a Trans- and Supranational Polity 1950-72, (NewYork:Routledge, 2009).

Reid,T.R., Avrupa Birleşik Devletleri: Yeni Süpergüç ve Amerikan Üstünlüğünün Sonu, Nur Küçük (Çev.), (Salyangoz Yayınları, 2007).

Romano PRODI, "Transkript in English of the Internet Chat with the President Romano Prodi", European Commission, Directorate-General Pres and Communication, (6.12.2001).

Romero, Sean., "European Integration and its Implications on the Decline of State Sovereignty", Federalism, Vol.4, February 2004.

Sander, Oral., Dünya Siyasi Tarihi: 1918-1994, (Ankara: İmge Kitabevi, Nisan 2002).

Seyidoğlu, Halil., Uluslararası Iktisat, (İstanbul: Güzem Yayınları, 2001).

Stein, Arthur A., "Neoliberal Institutionalism", İçinde Christian Reus-Smit ve Duncan Snidal, International Relations, (Oxford University Press, 2010).

YIL: 5 SAYI: 10 
AVRUPA BÜTÜNLEŞMESI SÜRECINDE: HUKUK, DEVLET VE EGEMENLIK,,,' 99

Taylor ,Paul., “The European Union in the 1990s”, İçinde Ngaire Woods (der.), Explaining International Relations Since 1945.

Tekinalp, Tekinalp., Avrupa Birliği Hukuku, (İstanbul: Beta Basım Yayın, 1997).

Temporten, Paul., The Euro, (New York: John Wiley\&Sons, 1998).

Tezcan, Ercüment., Avrupa Birliği Hukukunda Birey, (İstanbul: İletişim Yayınlar1, 2002).

Tezcan, Ercüment., Avrupa Birliği Kurumlar Hukuku, USAK, (Ankara:Siyasal Yayınevi, 2005).

Urwin, Derek W., The Community of Europe: A History of European Integration Since 1945, (London: Longman, 1995).

Ülger, İrfan Kaya., Avrupa Birliğinde Siyasal Bütünleşme, (İstanbul: Gündoğan Yayınları, Mayıs 2002).

Ünal, Şeref., “Tarihi Süreçte Türkiye-AB İlişkileri ve AB’nin Hukuki Yapısı”, Yeni Türkiye, Y11.6, Say1.35, Eylül-Ekim 2000.

Vandamme, Jacques., “European federalism: Opportunity or Utopia?”, İçinde Martin Westlake (der.), The European Union Beyond Amsterdam: New Concepts of European Integration, (London: Routledge, 1998).

Verdin, Hubert., Siyaset Tarhinde Bir Lider: Mitterand'ın Dünyalarl: Elsée Sarayı'nda 1981-1995, Engin Sunar (çev.), (Aksoy Yayıncılık, Ağustos 1999).

Waever, Ole.- Kelstrup, Morten., “ Europe and its Nations: Political and Cultural Identities" İçinde, Waever, Buzan, Keltsrup, Lemaitre, Identity and The New Security Agenda in Europe, (London: Printer Publishers 1993).

Wallace,William., "Less Than a Federation, More Than a Regime", in William Wallace, "The Sharing of Sovereignty: the European Paradox", Political Studies, Vol.XLVII, 1999.

Wallace,William., "The Sharing of Sovereignty: The European Paradox", Political Studies, Vol. XLVII, 1999.

Zararsız, M. Emin "Avrupa Topluluğu Hukukunun Doğrudan Etkisi Prensibi ve Türk Hukukunda Muhtemel Sonuçları”, Yeni Türkiye: Avrupa Birliği Özel Sayısı, S.35, Y.6 , Eylül-Ekim 2000.

Zielonka, Jan., Europe as Empire: The Nature of Enlarged European Union, (Oxford University Press, 2006). 